\title{
Carbon nanotubes as cancer therapeutic carriers and mediators
}

\author{
This article was published in the following Dove Press journal: \\ International Journal of Nanomedicine \\ 7 October 2016 \\ Number of times this article has been viewed
}

\author{
Kuk Hui Son' \\ Jeong Hee Hong ${ }^{2}$ \\ Jin Woo Lee $^{3}$ \\ 'Department of Thoracic and \\ Cardiovascular Surgery, Gachon \\ University Gil Medical Center, \\ 2Department of Physiology, \\ ${ }^{3}$ Department of Molecular Medicine, \\ School of Medicine, Gachon \\ University, Incheon, Republic of Korea
}

\begin{abstract}
Carbon nanotubes (CNTs) have received increasing attention in biomedical fields because of their unique structures and properties, including high aspect ratios, large surface areas, rich surface chemical functionalities, and size stability on the nanoscale. Particularly, they are attractive as carriers and mediators for cancer therapy. Through appropriate functionalization, CNTs have been used as nanocarriers for anticancer drugs including doxorubicin, camptothecin, carboplatin, cisplatin, paclitaxel, Pt(II), and Pt(IV), and genes including plasmid DNA, smallinterfering RNA, oligonucleotides, and RNA/DNA aptamers. CNTs can also deliver proteins and immunotherapy components. Using combinations of light energy, they have also been applied as mediators for photothermal therapy and photodynamic therapy to directly destroy cancer cells without severely damaging normal tissue. If limitations such as a long-term cytotoxicity in the body, lack of size uniformity during the synthetic process, loading deviations for drug-CNT complexes, and release controllability at the target point are overcome, CNTs will become one of the strongest tools that are available for various other biomedical fields as well as for cancer therapy.
\end{abstract}

Keywords: carbon nanotubes, cancer, therapy, carrier, mediator

\section{Introduction}

Cancer is defined as the uncontrolled growth of cells that destroys normal tissues and organs. ${ }^{1}$ Various mutations and uncontrolled growth and division of cancerous cells allow cancer cells to acquire properties such as self-sufficiency in growth signals, unlimited proliferation potential, and resistance to signals that stop proliferation or induce apoptosis by normal cells. ${ }^{2}$ Tumors have evolved to utilize additional supports via interactions with surrounding stromal cells, promotion of angiogenesis, evasion of immune detecting systems, and metastasis to other organs. ${ }^{3}$

According to a report from the Cancer Research Organization in the UK in 2012, more than 14 million new cases of cancer and more than 8.9 million cancer-related deaths occur each year. ${ }^{1}$ According to the World Health Organization, the most frequent types of cancers causing death include lung, stomach, liver, colon, and breast cancers. ${ }^{4}$ Although currently available technologies have made enormous advances in cancer research, a cancer-specific therapy that does not damage normal tissue and can be used for cancer detection during early stages is not available.

Nanotechnology is the manipulation of matter, including the synthesis, assembly, control, and measurement, on the atom and molecular level. Since the concept of nanomanipulation was established, this technology has been used in a number of applications in various fields such as electronics, mechanics, chemistry, and biology. Furthermore, nanotechnology has been applied in biomedical fields for detection, diagnosis, imaging,
Correspondence: Jin Woo Lee

Department of Molecular Medicine, School of Medicine, Gachon University, I55, Gaetbeol-ro, Yeonsu-ku, Incheon 21999 , Republic of Korea

$\mathrm{Tel}+82328996516$

Fax +82 328996039

Email jwlee@gachon.ac.kr
International Journal of Nanomedicine 2016:1 | 5163-5185

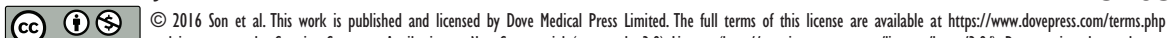
cc. hereby accept the Terms. Non-commercial uses of the work are permitted without any further permission from Dove Medical Press Limited, provided the work is properly attributed. For permission for commercial use of this work, please see paragraphs 4.2 and 5 of our Terms (https://www.dovepress.com/terms.php). 


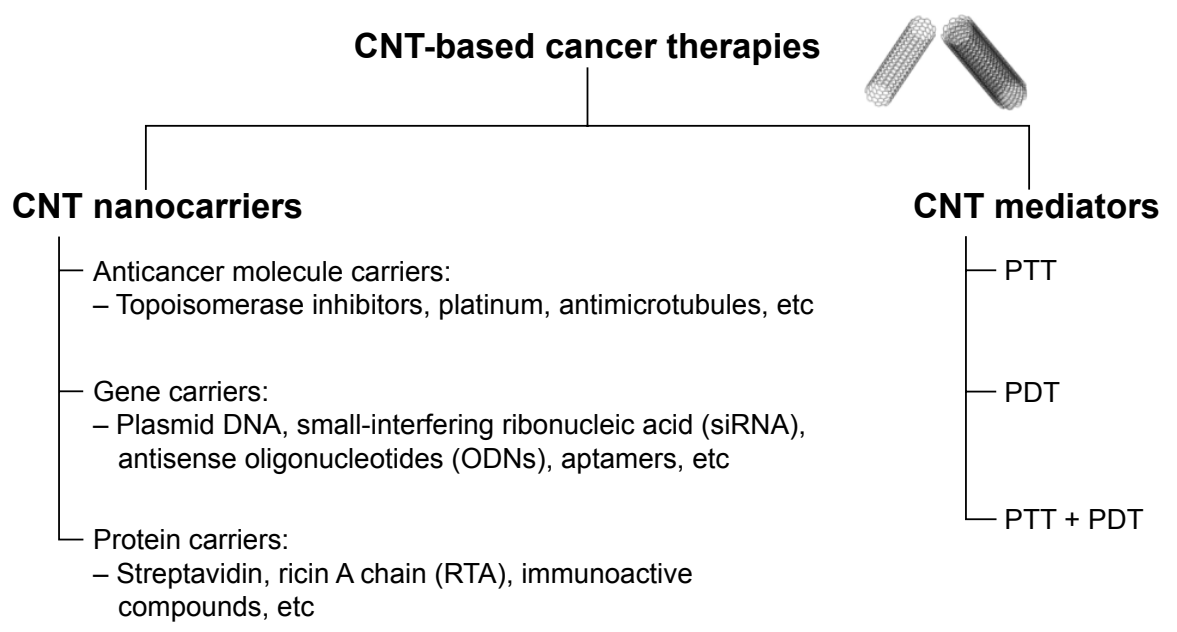

Figure I CNT-based cancer therapies.

Abbreviations: CNTs, carbon nanotubes; ODNs, oligonucleotides; PDT, photodynamic therapy; PTT, photothermal therapy; RTA, ricin A chain; siRNA, small-interfering ribonucleic acid.

and therapy. As introduced in the book Fantastic Voyage by Isaac Asimov, the use of miniature particles has enabled the successful use of nanotechnology in the medical field and has been examined in numerous studies.

Nanotechnology-based products used in biomedicine typically include nanoparticles (NPs), which can be classified as organic NPs and inorganic NPs. Liposomes, dendrimers, virus, solid lipid NPs, and polymeric NPs are organic NPs and have been utilized in cancer therapy and diagnosis for a long time. Gold, silver, silica, magnetic particles, ceramic particles, quantum dots, and carbon particles are inorganic NPs and are considered to be promising vectors for cancer treatment.

After the discovery of carbon nanotubes (CNTs) by Sumio Iijima in 1991, they have received a great deal of attention in biomedical fields because of their unique structures and properties, including high aspect ratios, large surface areas, rich surface chemical functionalities, and size stability on the nanoscale. ${ }^{5}$ Particularly, they are attractive as transporters for the delivery of biomolecules and drugs. ${ }^{6}$ Through appropriate functionalization, CNTs have been used as nanocarriers to transport anticancer drugs, genes, and proteins for chemotherapy. They have also been used as mediators for photothermal therapy (PTT) and photodynamic therapy (PDT) to directly destroy cancer cells. Therefore, we describe the achievements related to the use of CNTs for cancer therapy as delivery vectors and destruction mediators (Figure 1).

\section{CNTs as carriers of molecules, genes, and proteins}

CNTs have high aspect ratios and are very small, and thus they have high specific surface areas, related to their needle-like shapes, enabling them to adsorb onto or conjugate with various therapeutic molecules. The needle-like shape of CNTs also enables their internalization into target cells. Therefore, CNTs are considered as promising nanocarriers for the delivery of drugs, genes, and proteins. However, because vesicle-based carriers such as liposomes have decreased other diseases other than cancer, CNT-based nanocarriers have been widely studied for the delivery of anticancer agents (the summary of CNTs as cancer therapeutic carriers described in this review is given in Table 1).

\section{CNTs as carriers of anticancer molecules}

Traditionally, chemotherapy is used to diminish cancers with other treatment techniques such as radiation and surgery. However, during treatment, undesirable toxicity narrows the therapeutic window, and the nonspecificity of drugs can increase drug resistance. ${ }^{7}$ Therefore, new methods for delivering anticancer molecules specifically to tumors to reduce side effects and improve therapeutic efficacy are greatly needed. In this section, the common uses of CNTs for the delivery of anticancer drugs, including topoisomerase inhibitors, platinum (Pt)-based drugs, and antimicrotubules, are examined.

\section{CNTs as topoisomerase inhibitor carriers}

Some chemotherapeutic agents arrest DNA replication and subsequent apoptosis, and then slow the growth of cancer cells by inhibiting the activity of eukaryotic topoisomerases. These agents are collectively known as topoisomerase inhibitors. Clinically used topoisomerase I inhibitors include irinotecan, topotecan, and camptothecin (CPT) and topoisomerase II inhibitors include etoposide (ETO) and teniposide. In addition, 
Table I Summary of CNTs as cancer therapeutic carriers described in this review

\begin{tabular}{|c|c|c|c|c|}
\hline Component & CNT system & $\begin{array}{l}\text { Biological studies } \\
\text { (in vitro/in vivo) }\end{array}$ & Results & References \\
\hline CPT & $\begin{array}{l}\text { Oxidized MWCNTs coated with } \\
\text { Pluronic PI } 23\end{array}$ & In vitro: HeLa & $\begin{array}{l}\text { CNT complexes exhibited enhanced } \\
\text { antitumor activity over free CPT }\end{array}$ & 8 \\
\hline HCPT & $\begin{array}{l}\text { f-MWCNTs (diaminotriethylene } \\
\text { glycol spacers) }\end{array}$ & $\begin{array}{l}\text { In vitro: } M K N-28 \\
\text { In vivo: mice bearing } \\
\text { hepatic } \mathrm{H} 22 \text { tumors }\end{array}$ & $\begin{array}{l}\text { HCPT-MWCNTs conjugates showed } \\
\text { a superior antitumor activity to clinical } \\
\text { HCPT formulations }\end{array}$ & 9 \\
\hline Irinotecan & MWCNTs (open tips) & - & $\begin{array}{l}\text { A larger inner diameter tube exhibited } \\
\text { higher filling amount of irinotecan than } \\
\text { smaller one }\end{array}$ & 10 \\
\hline ETO & f-SWCNT-COOH (CS and EGF) & In vitro: A549 & $\begin{array}{l}\text { The death of A549 induced by EGF/CS/ } \\
\text { SWCNT-COOHs/ETO was } 2.7 \text {-fold } \\
\text { higher than ETO alone case }\end{array}$ & II \\
\hline \multirow[t]{5}{*}{ DOX } & $\begin{array}{l}\text { f-SWCNTs ([CS and/or ALG] } \\
\text { and FA) }\end{array}$ & In vitro: HeLa & $\begin{array}{l}\text { CNT complexes released the DOX at } \\
\text { low pH }\end{array}$ & 13 \\
\hline & f-SWCNTs (PEG and cyclic RGD) & In vitro: U87MG, MCF-7 & $\begin{array}{l}\text { The PEG-SWCNTs exhibited an } \\
\text { extremely high loading efficiency } \\
\text { of } \sim 400 \%\end{array}$ & 20 \\
\hline & MWCNTs (dispersed Pluronic FI27) & In vitro: MCF-7 & $\begin{array}{l}\text { Complexes showed enhanced } \\
\text { cytotoxicity on human breast cancer } \\
\text { cells, MCF-7 }\end{array}$ & 21 \\
\hline & f-MWCNTs (FA and iron NP) & In vitro: HeLa & $\begin{array}{l}\text { The dual targeting method showed } \\
\text { sixfold higher delivering ability than free } \\
\text { DOX into the HeLa cells }\end{array}$ & 22 \\
\hline & f-MWCNTs $\left(\mathrm{CoFe}_{2} \mathrm{O}_{4}\right)$ & In vitro: HeLa & $\begin{array}{l}\text { The DOX-loaded hybrids exhibited } \\
\text { notable cytotoxicity to HeLa cancer cells } \\
\text { due to the intracellular release of DOX }\end{array}$ & 30 \\
\hline EPI & $\begin{array}{l}\text { MWCNTs with or without }-\mathrm{COOH} \\
\text { groups and SWCNTs }\end{array}$ & - & $\begin{array}{l}\text { Adsorption efficiency and drug loading } \\
\text { of c-MWCNTs were higher than } \\
\text { unmodified MWCNTs }\end{array}$ & 32 \\
\hline DAU & f-SWCNTs (sgc8c aptamer) & In vitro: Molt-4, U266 & $\begin{array}{l}\text { The system accomplished higher uptake } \\
\text { and selectivity toward target cell line } \\
\text { (Molt-4) than nontarget cell line (U266) } \\
\text { compared to free DAU }\end{array}$ & 33 \\
\hline \multirow[t]{3}{*}{ CDDP } & f-SWCNTs (PL-PEG-NH ${ }_{2}$ ) & In vitro: JAR, KB, NTera-2 & $\begin{array}{l}\text { SWCNTs internalization, CDDP release } \\
\text { and interaction between the nucleus and } \\
\text { CDDP were progressed }\end{array}$ & 39 \\
\hline & SWCNTs & In vitro: PC-3, DUI45 & $\begin{array}{l}\text { In vitro release profile of CDDP- } \\
\text { SWCNTs was smooth until } 72 \text { hours and } \\
\text { a maximum release percentage was } 68 \%\end{array}$ & 41 \\
\hline & f-magnetic CNTs (PL-PEG-FA) & - & $\begin{array}{l}\text { The magnetic CNTs were retained in the } \\
\text { draining targeted lymph nodes for several } \\
\text { days and continuously released drugs }\end{array}$ & 48 \\
\hline $\mathrm{CP}$ & Open-ended oxidized MWCNTs & In vitro: EJ28 & $\begin{array}{l}\text { CP-MWCNTs inhibited growth of } \\
\text { urinary bladder cancer cells }\end{array}$ & 50 \\
\hline \multirow[t]{5}{*}{ PTX } & SWCNTs & In vitro: $\mathrm{A} 549, \mathrm{NCl}-\mathrm{H} 460$ & $\begin{array}{l}\text { SWCNTs increased the PTX activity } \\
\text { against lung cancer by ROS-dependent } \\
\text { synergy between CNTs and PTX }\end{array}$ & 53 \\
\hline & SWCNTs & In vitro: OVCAR3 & $\begin{array}{l}\text { PTX-conjugated SWCNTs sensitized } \\
\text { human ovarian cancer OVCAR3 cells and } \\
\text { resulted in higher cell death }\end{array}$ & 54 \\
\hline & f-MWCNTs (hyperbranched PCA) & In vitro: $\mathrm{A} 549, \mathrm{SKOV} 3$ & $\begin{array}{l}\text { MWCNTs-g-PCA-PTX had a more } \\
\text { cytotoxic effect than the free drug }\end{array}$ & 56 \\
\hline & f-SWCNTs (PEG phospholipids) & $\begin{array}{l}\text { In vitro: } 4 \mathrm{TI} \\
\text { In vivo: Mice bearing } \\
4 \mathrm{TI} \text { tumors }\end{array}$ & $\begin{array}{l}\text { PTX uptake into the tumor of PTX- } \\
\text { SWCNTs was ten times higher than } \\
\text { clinical Taxol }{ }^{\circledR} \text { in a murine } 4 \text { TI breast } \\
\text { cancer model }\end{array}$ & 58 \\
\hline & f-SWCNTs and f-MWCNTs (PEG) & In vitro: MCF-7, HeLa & $\begin{array}{l}\text { PEG-CNTs suppressed the growth of } \\
\text { MCF-7 cancer cells and HeLa cells }\end{array}$ & 59 \\
\hline
\end{tabular}


Table I (Continued)

\begin{tabular}{|c|c|c|c|c|}
\hline Component & CNT system & $\begin{array}{l}\text { Biological studies } \\
\text { (in vitro/in vivo) }\end{array}$ & Results & References \\
\hline DTX & $\begin{array}{l}\text { f-SWCNTs (PVP K } 30 \text { and DSPE- } \\
\text { PEG-maleimide linked with NGR } \\
\text { peptide, combined with NIR- } \\
\text { induced PTT) }\end{array}$ & $\begin{array}{l}\text { In vitro: } \mathrm{PC}-3 \\
\text { In vivo: Mice bearing } \\
\text { s } 180 \text { tumors }\end{array}$ & $\begin{array}{l}\text { DTX-NGR-SWCNTs showed higher } \\
\text { suppression efficacy of tumor growth } \\
\text { than DTX in a PC-3 in vitro and in vivo } \\
\text { model }\end{array}$ & 63 \\
\hline \multirow[t]{6}{*}{ pDNA } & $\begin{array}{l}\text { f-SWCNTs and f-MWCNTs } \\
\left(\mathrm{NH}_{2}-\mathrm{SWCNTs}, \mathrm{NH}_{2}-\mathrm{MWCNTs}\right)\end{array}$ & In vitro: HeLa & $\begin{array}{l}\text { f-SWCNTs facilitated higher pDNA } \\
\text { uptake and gene expression in vitro than } \\
\text { pDNA alone }\end{array}$ & 64 \\
\hline & f-MWCNTs (MWCNTs-NH ${ }_{2}$ ) & In vitro: $\mathrm{A} 375$ & $\begin{array}{l}\mathrm{NH}_{2}-\mathrm{MWCNT} \text { interact with pDNA and } \\
\text { deliver the GFP gene in cultured cells. } \\
\text { Although transfection efficiency was } \\
\text { low, } \sim 5 \%\end{array}$ & 65 \\
\hline & $\begin{array}{l}\text { SWCNTs- } \mathrm{NH}_{3}^{+} \\
\text {MWCNTs- } \mathrm{NH}_{3}^{+} \\
\text {sWCNT-Lys- } \mathrm{NH}_{3}^{+}\end{array}$ & In vitro: A549 & $\begin{array}{l}\text { All three } \mathrm{f} \text {-CNTs exhibited upregulation } \\
\text { of marker gene expression over naked } \\
\text { DNA }\end{array}$ & 66 \\
\hline & f-MWCNTs (CS-FA NPs) & In vitro: HeLa, MCF-7 & $\begin{array}{l}\text { f-MWCNTs showed an increased } \\
\text { transfection efficiency and decreased } \\
\text { cytotoxicity }\end{array}$ & 67 \\
\hline & f-MWCNT PEls & $\begin{array}{l}\text { In vivo: transfection in } \\
\text { vein injection (mice) }\end{array}$ & $\begin{array}{l}\text { A transfection efficiency of PEI- } \\
\text { functionalized CNTs was up to I9-fold } \\
\text { higher than that of underivatized PEls }\end{array}$ & 68 \\
\hline & f-SWCNTs (ethylenediamine) & In vitro: MCF-7 & $\begin{array}{l}\text { A strong expression of p53 led to } 40 \% \\
\text { apoptosis after } 72 \text {-hour exposure }\end{array}$ & 72 \\
\hline \multirow[t]{5}{*}{ siRNA } & f-SWCNTs (SWCNT-NH ${ }_{2}$ ) & In vitro: K562 & $\begin{array}{l}\text { A depletion of cyclin A2 inhibited cell } \\
\text { proliferation and promoted apoptosis of } \\
\text { chronic myelogenous leukemia K562 cells }\end{array}$ & 76 \\
\hline & f-MWCNTs (PEI and pyridinium) & In vitro: HI299 & $\begin{array}{l}\text { Both f-CNTs: siRNA complexes showed } \\
10 \%-30 \% \text { silencing activity and a } \\
\text { cytotoxicity of } 10 \%-60 \%\end{array}$ & 77 \\
\hline & f-MWCNTs (MWCNT-NH ${ }_{3}^{+}$) & $\begin{array}{l}\text { In vitro: Calu6, SVEC } \\
\text { 4-I0 and 2F2B, DUI45 } \\
\text { and C-33A, A549, MCF-7, } \\
\text { HeLa, HEK293, BI6FI0, } \\
\text { NIH 3T3 } \\
\text { In vivo: mice bearing } \\
\text { Calu6 xenograft tumors }\end{array}$ & $\begin{array}{l}\text { MWNT- } \mathrm{NH}_{3}^{+} \text {: siRNA complexes elicited } \\
\text { delayed tumor growth and increased the } \\
\text { survival of xenograft-bearing animals }\end{array}$ & 78 \\
\hline & $\begin{array}{l}\text { f-SWCNTs }\left(-\mathrm{CONH}-\left(\mathrm{CH}_{2}\right)_{6}^{-}\right. \\
\left.\mathrm{NH}_{3}{ }^{+} \mathrm{Cl}^{-}\right)\end{array}$ & $\begin{array}{l}\text { In vitro: TC-I cells, IH8 } \\
\text { cells, LLC cells } \\
\text { In vivo: mice bearing } \\
\text { Lewis lung carcinoma or } \\
\text { HeLa cell xenografts }\end{array}$ & $\begin{array}{l}\text { An injection of mTERT siRNA: SWCNT + } \\
\text { complexes into subcutaneous injected } \\
\text { Lewis lung tumors reduced tumor growth } \\
\text { (in vivo) }\end{array}$ & 79 \\
\hline & Pristine SWCNTs & $\begin{array}{l}\text { In vitro: MiaPaCa-2/HRE, } \\
\text { MCF-7, MDA-MB-23I, } \\
\text { RGMI } \\
\text { In vivo: mice bearing } \\
\text { MiaPaCa-2/HRE tumors }\end{array}$ & $\begin{array}{l}\text { An intratumoral injection of SWCNT: } \\
\text { siRNA complexes inhibited HIF-I } \alpha \\
\text { expression, but tumor growth } \\
\text { suppression was short lived }\end{array}$ & 89 \\
\hline \multirow[t]{2}{*}{ ODNs } & $\begin{array}{l}\text { f-MWCNTs (-COOH, -PEI, } \\
\text {-PDDA, -PAMAM, -CS) }\end{array}$ & In vitro: HeLa & $\begin{array}{l}\text { PEI-MWCNTs demonstrated efficient } \\
\text { intracellular transporting, strong cell } \\
\text { nucleus localization, and high delivery } \\
\text { efficiency of ASODNs }\end{array}$ & 93 \\
\hline & $\begin{array}{l}\text { f-MWCNTs (polyamidoamine } \\
\text { dendrimer modified) }\end{array}$ & $\begin{array}{l}\text { In vitro: MCF-7, MDA- } \\
\text { MB-435, HepG2 }\end{array}$ & $\begin{array}{l}\text { These composites inhibited the cell } \\
\text { growth by time- and dose-dependent } \\
\text { means, and downregulated the } \\
\text { expression of C-Myc gene and C-Myc } \\
\text { protein }\end{array}$ & 94 \\
\hline Aptamer & f-MWCNTs $(-\mathrm{COOH})$ & In vitro: MCF-7 & $\begin{array}{l}\text { MWCNT-aptamer conjugates were } \\
\text { internalized without affecting cell viability }\end{array}$ & 95 \\
\hline
\end{tabular}


Table I (Continued)

\begin{tabular}{|c|c|c|c|c|}
\hline Component & CNT system & $\begin{array}{l}\text { Biological studies } \\
\text { (in vitro/in vivo) }\end{array}$ & Results & References \\
\hline & $\begin{array}{l}\text { f-SWCNTs (RNA aptamer-PEI- } \\
\text { piperazine) }\end{array}$ & $\begin{array}{l}\text { In vitro: EpCAM-positive/ } \\
\text { negative cells }\end{array}$ & $\begin{array}{l}\text { Conjugates induced a specific apoptosis } \\
\text { by }>20 \% \text { in EpCAM-positive cells rather } \\
\text { than EpCAM-negative cells }\end{array}$ & 99 \\
\hline \multirow[t]{5}{*}{ Protein } & $\begin{array}{l}\text { Streptavidin-conjugated SWCNTs- } \\
\text { biotin }\end{array}$ & $\begin{array}{l}\text { In vitro: } \mathrm{HL60} \text {, human } \\
\text { T-cells }\end{array}$ & $\begin{array}{l}\text { An uptake pathway of the conjugates was } \\
\text { consistent with endocytosis }\end{array}$ & 101 \\
\hline & $\begin{array}{l}\text { f-SWCNTs and f-MWCNTs } \\
(\text { BSA-AZc6) }\end{array}$ & $\begin{array}{l}\text { In vivo: New Zealand } \\
\text { rabbits, } B A L B / c \text { mice }\end{array}$ & $\begin{array}{l}\text { Among four types of CNT-BSA-AZc6 } \\
\text { constructs, the short and thick one } \\
\text { showed the best antibody response } \\
\text { under all tested conditions }\end{array}$ & 102 \\
\hline & f-MWCNTs (toxin protein RTA) & $\begin{array}{l}\text { In vitro: L-929, HeLa, } \\
\text { HL7702, MCF-7, COS-7 }\end{array}$ & $\begin{array}{l}\text { RTA-MWCNTs conjugates were } \\
\text { three times higher than cell death rates } \\
\text { achieved by RTA alone }\end{array}$ & 103 \\
\hline & f-MWCNTs (CS NP) & In vitro: HeLa cells & $\begin{array}{l}\text { MWCNTs-CS NP hybrids improved the } \\
\text { immobilization efficiency and decreased } \\
\text { the cellular toxicity }\end{array}$ & 104 \\
\hline & $\begin{array}{l}\text { f-SWCNTs (amphiphilic } \\
\text { polypeptides) }\end{array}$ & - & $\begin{array}{l}\text { A model to predict the SWCNT } \\
\text { adsorption and dispersion properties of } \\
\text { natural proteins was developed }\end{array}$ & 105 \\
\hline \multirow[t]{7}{*}{$\begin{array}{l}\text { Immunoactive } \\
\text { compounds }\end{array}$} & $\begin{array}{l}\text { f-SWCNTs (radiometal-ion chelates, } \\
\text { E4GI0) }\end{array}$ & $\begin{array}{l}\text { In vivo: mice bearing } \\
\text { LSI74T }\end{array}$ & $\begin{array}{l}\text { The complexes reduced tumor volume } \\
\text { and improved median survival relative to } \\
\text { controls }\end{array}$ & 107 \\
\hline & MWCNTs & $\begin{array}{l}\text { In vivo: mice bearing } \\
\text { hepatic } \mathrm{H} 22 \text { tumors }\end{array}$ & $\begin{array}{l}\text { Injected MWCNTs induced activation } \\
\text { of the complement system, promoted } \\
\text { the production of inflammatory } \\
\text { cytokines, and stimulated phagocytosis of } \\
\text { macrophages, leading to the inhibition of } \\
\text { a tumor growth }\end{array}$ & 108 \\
\hline & MWCNTs & $\begin{array}{l}\text { In vivo: mice bearing } \\
\text { GL26I }\end{array}$ & $\begin{array}{l}\text { Injected MWCNTs increased the influx } \\
\text { of macrophages into the glioma cells and } \\
\text { caused an increase of tumor cytokine } \\
\text { level (IL-I0) }\end{array}$ & 111 \\
\hline & $\begin{array}{l}\text { f-Bundled CNTs (MHC-I, } \alpha \text { CD28, } \\
\text { PLGA) }\end{array}$ & $\begin{array}{l}\text { In vivo: mice bearing } \mathrm{B} \mid 6 \\
\text { melanoma }\end{array}$ & $\begin{array}{l}\text { CNTs-polymer composite acted as an } \\
\text { artificial APC to expand T-cells efficiently }\end{array}$ & 112 \\
\hline & f-SWCNTs (CpG) & $\begin{array}{l}\text { In vivo: mice bearing } \\
\text { subcutaneous melanomas }\end{array}$ & $\begin{array}{l}\text { Intracranial CNTs-CpG therapy inhibited } \\
\text { not only the growth of brain tumors but } \\
\text { also subcutaneous melanomas }\end{array}$ & 113 \\
\hline & f-SWCNTs (PEG, GITR ligands) & $\begin{array}{l}\text { In vivo: mice bearing BI6 } \\
\text { melanoma }\end{array}$ & $\begin{array}{l}\text { PEG-SWCNTs with GITR ligands } \\
\text { targeted } T_{\text {reg }} \text { residing in a BI6 melanoma } \\
\text { more efficiently than intratumor non- } \mathrm{T}_{\text {reg }} \\
\text { or splenic } \mathrm{T}_{\text {reg }}\end{array}$ & 117 \\
\hline & f-SWCNTs (tumor lysate protein) & $\begin{array}{l}\text { In vivo: mice bearing } \\
\text { hepatic } \mathrm{H} 22 \text { tumors }\end{array}$ & $\begin{array}{l}\text { Efficacy of a tumor cure and cellular } \\
\text { antitumor immune reaction in tumor } \\
\text { lysate protein-conjugated CNTs were } \\
\text { markedly improved }\end{array}$ & 118 \\
\hline
\end{tabular}

Abbreviations: APC, antigen-presenting cell; ASODNs, antisense oligodeoxynucleotides; BSA, bovine serum albumin; CDDP, cis-dichlorodiammineplatinum; CNTs, carbon nanotubes; c-MWCNTs, carboxylated MWCNTs; CP, cis-diammine(I,I-cyclobutanedicarboxylato) platinum(II); CPT, camptothecin; CS, chitosan; DAU, daunorubicin; DOX, doxorubicin; DTX, docetaxel; EGF, epidermal growth factor; EpCAM, epithelial cell adhesion molecule; EPI, epirubicin; ETO, etoposide; f, functionalized; FA, folic acid; GITR, glucocorticoid-induced TNFR-related receptor; HCPT, I0-hydroxycamptothecin; HIF-I $\alpha$, hypoxia inducible factor I $\alpha$; IL-I0, interleukin-I0; MWCNTs, multiwalled carbon nanotubes; NGR, Asn-Gly-Arg; NP, nanoparticle; NIR, near infrared; ODNs, oligonucleotides; PC-3, prostate cancer cell; pDNA, plasmid DNA; PEls, polyethyleneimines; PCA, poly(citric acid); PEG, polyethylene glycol; PL, phospholipid; PTT, photothermal therapy; PTX, paclitaxel; ROS, reactive oxygen species; siRNA, small-interfering RNA; SWCNTs, single-walled carbon nanotubes; $T_{\text {reg }}$, regulatory T-cell; ALG, alginate; RGD, Arg-Gly-Asp; PVP, polyvinylpyrrolidone; DSPE, I,2-distearoyl-sn-glycero-3-phosphoethanolamine; PDDA, polydiallyldimethylammonium chloride; PAMAM, polyamidoamine; MHC-I, peptideloaded major histocompatibility complex class-I; PLGA, polylacticglycolic acid.

anthracyclines, including doxorubicin (DOX), epirubicin (EPI), and daunorubicin (DAU), represent a unique class of anticancer drugs that can also inhibit topoisomerase II.

In a study of topoisomerase I inhibitors, Tian et $\mathrm{al}^{8}$ prepared CPT-loaded multiwalled CNTs (MWCNTs) with tri-block copolymer through $\pi-\pi$ stacking interactions to improve antitumor activity. To enhance aqueous solubility, the MWCNTs were coated with the tri-block copolymer Pluronic P123. The polymer-coated MWCNTs could effectively form non-covalent supramolecular complexes 
with CPT. In vitro cytotoxicity studies using HeLa cells showed that these complexes had enhanced antitumor activity compared to free CPT. These results suggest that functionalized MWCNTs improve the activity of anticancer drugs. However, an additional in vivo study was required to confirm the antitumor activity of CPT.

To increase the water solubility and antitumor activity, 10-hydroxycamptothecin (HCPT), which is similar to CPT, is utilized. Wu et $\mathrm{al}^{9}$ developed an MWCNT-based drug delivery system conjugated to HCPT. In both in vitro and in vivo tests, the HCPT-MWCNT conjugates showed superior antitumor activity to clinical HCPT formulations
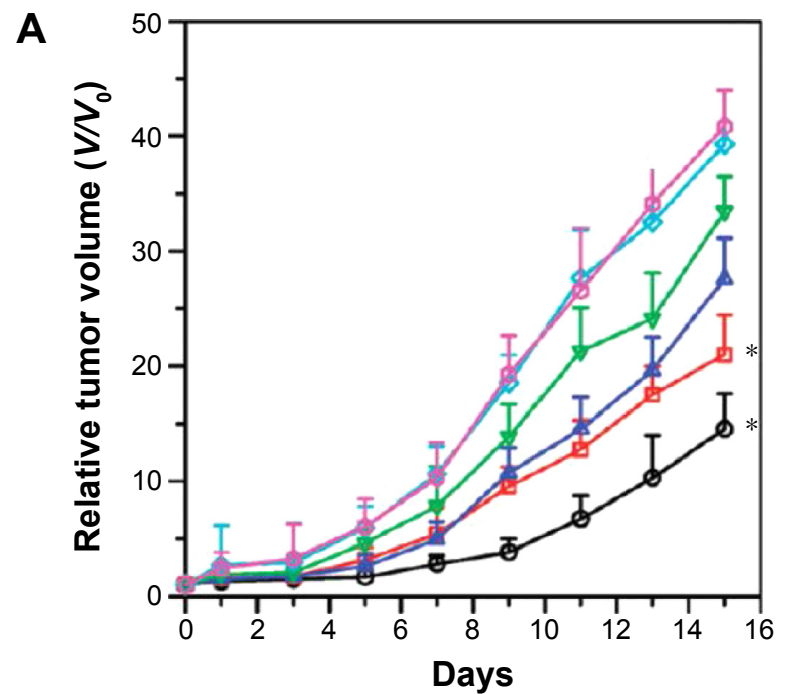

(Figure 2). Based on in vivo single-photon emissioncomputed tomography and ex vivo gamma-scintillation counting analyses, these conjugates showed a long circulation time $(\sim 3.6$ hours $)$ in the blood and high accumulation level $(\sim 3.6 \%$ injected dose per gram of tissue [ID/g]) in the tumor area.

Tripisciano et $\mathrm{al}^{10}$ encapsulated the antineoplastic agent, irinotecan, a more water-soluble semisynthetic analog of CPT, within MWCNTs. From the experiment, it was observed that a larger inner diameter tube exhibited higher filling amount of irinotecan than a smaller one and a loading efficiency of $32 \%$ was achieved. Because the stability and hydrophilicity of irinotecan are increased under acidic

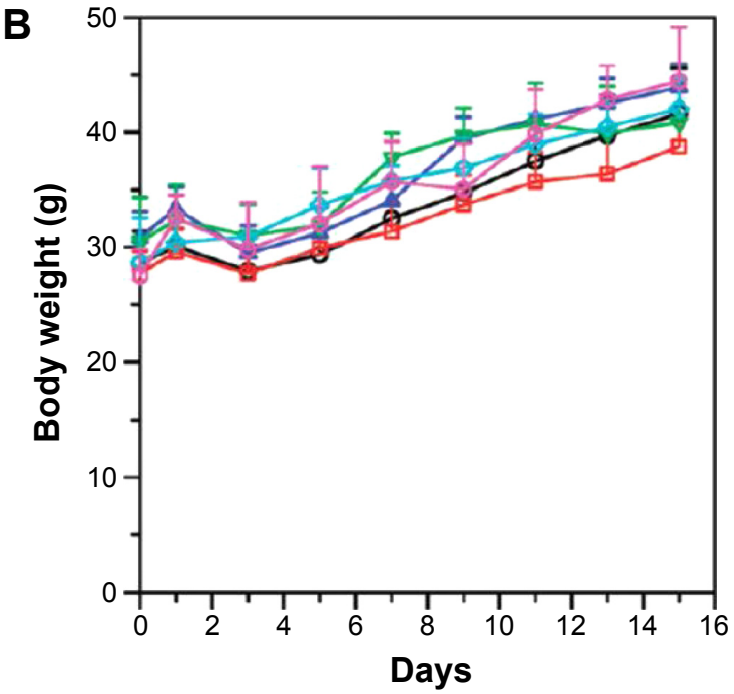

$\begin{array}{ll}\rightarrow-\text { MWCNTs 3-5 mg/kg eq } & - \text { MWCNTs 3-2.5 mg/kg eq } \\ - \text { HCPT injection }-5 \mathrm{mg} / \mathrm{kg} \text { eq } & - \text { HCPT injection }-2.5 \mathrm{mg} / \mathrm{kg} \text { eq } \\ - \text { MWCNTs } 2 & - \text { Saline }\end{array}$

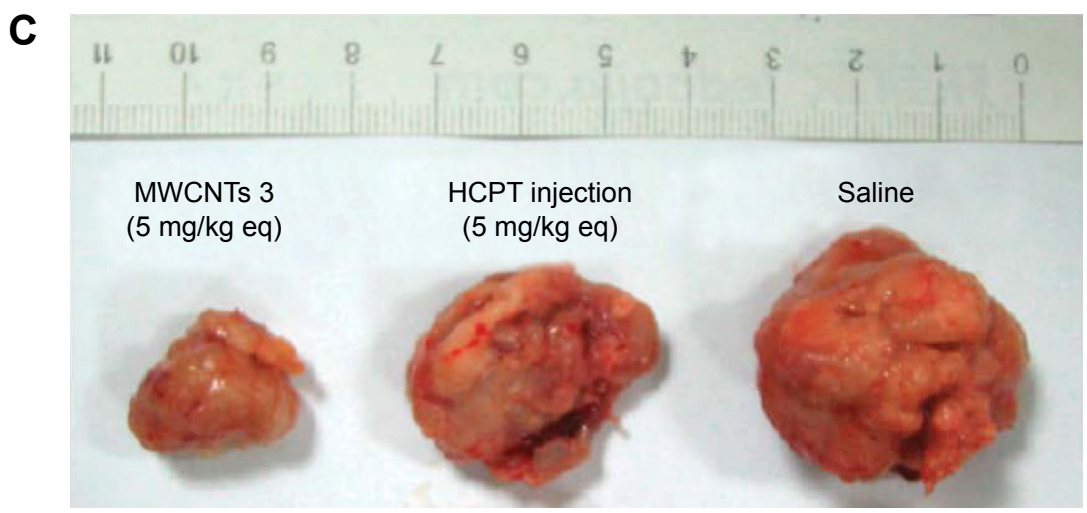

Figure 2 In vivo antitumor effects by various treatments.

Notes: (A) In vivo antitumor effect in each treated group, expressed as the average values of the relative tumor volume $V / V_{0}$ (where $V$ denotes the tumor volume at test time points and $V_{0}$ denotes the corresponding initial tumor volume at the beginning of treatment). $* P<0.05$ (vs HCPT injection group at the equivalent dose from the fifth day). (B) Evolution of body weight in each group during the experiments. Data in A and B are presented as mean $\pm S D$ ( $n=8$ ). (C) Typical photographs of excised sarcomas from mice on the 16th day after treatment with MWCNTs $3(5 \mathrm{mg} / \mathrm{kg}$ eq), HCPT injection (5 mg/kg eq) and saline. Reprinted with permission from Wu W, Li R, Bian X, et al. Covalently combining carbon nanotubes with anticancer agent: preparation and antitumor activity. ACS Nano. 2009;3(9):2740-2750. ${ }^{9}$ Copyright 2009 American Chemical Society. "2" and "3" represent MWCNTs 2 (amine salt-bearing MWCNTs) and MWCNTs 3 (HCPT conjugated MWCNTs), respectively.

Abbreviations: HCPT, 10-hydroxycamptothecin; MWCNTs, multiwalled carbon nanotubes; eq, equivalent. 
conditions, rapid and complete release was observed ( $\mathrm{pH} 6.0$ vs 7.0) in a mild acidic environment. However, in vitro analysis of colorectal cancer cells using this complex was not conducted.

Chen et $\mathrm{al}^{11}$ fabricated ETO-loaded epidermal growth factor (EGF)-chitosan (CS)-single-walled CNTs (SWCNTs; EGF/CS/SWCNT-COOHs/ETO). CS improved the water dispersibility of CNTs and served as a linker for conjugation with EGF. EGF/CS/SWCNT-COOHs showed only slight cytotoxicity and the loading capacity of ETO was $\sim 25 \%-27 \%(\mathrm{w} / \mathrm{w})$. The death of human alveolar carcinoma epithelial cells induced by EGF/CS/SWCNT-COOHs/ ETO was 2.7-fold higher than that of ETO alone. Their work revealed the potential of this new drug delivery system to enhance the efficacy of ETO.

Among anthracyclines, because the loading and release of DOX from CNTs can be manipulated by changing the $\mathrm{pH}$, coating molecules, and temperature, many studies have been attempted to improve therapeutic efficacy. ${ }^{12-19}$ Liu et $\mathrm{al}^{20}$ proposed a new drug delivery system using polyethylene glycol (PEG)-functionalized SWCNTs attached to DOX. Water-soluble SWCNTs by PEG functionalization exhibited an extremely high loading efficiency of $\sim 400 \%$. Their SWCNTs-DOX complexes showed good stability in normal physiological buffer as well as in the serum and acidic environments, which is an ideal property for in vivo drug carriers. Diameter-dependent binding and release of the drug in SWCNTs showed the potential for multiple choices for use in drug delivery. However, they merely studied in vitro cytotoxicity using U87MG and MCF-7 cell lines. Using a similar strategy, Ali-Boucetta et $\mathrm{al}^{21}$ formed MWCNT complexes with an aromatic chromophore and DOX via $\pi-\pi$ stacking interactions. Their complexes showed enhanced cytotoxicity in human breast cancer MCF-7 cells. However, cell viability was not decreased by DOX-free MWCNT carriers.

The therapeutic efficacy of DOX can be enhanced by conjugation with folic acid (FA), estradiol, dexamethasone, and antibody binding. ${ }^{22-29}$ Zhang et $\mathrm{l}^{13}$ developed a targeted delivery system using FA-tethered SWCNT-DOX. This system employed polysaccharides (sodium alginate and CS) to control the release of DOX, while FA was used to improve the targeting properties of CNTs. This system showed good stability under normal physiological $\mathrm{pH}(\mathrm{pH}$ 7.4) and efficiently released DOX at low $\mathrm{pH}$ such as in the tumor environment and intracellular lysosomes. Using a similar strategy, Li et al $^{22}$ synthesized a new delivery system by conjugating iron NPs and FA with MWCNTs. They improved the targeting efficiency of their nanocarriers by using an external magnetic field. The nanocarriers showed a sufficient load capacity of DOX and a long releasing time. Their dual targeting method showed sixfold higher delivery than that of free DOX into HeLa cells. They also developed a CNT-based magnetic dual-targeted nanocarrier for drug delivery. ${ }^{24}$ Their magnetic MWCNTs were conjugated to the targeting ligand FA to load the anticancer drug DOX. Under the guidance of a magnetic field and ligand receptor interactions, dualtargeted delivery of DOX into cancer cells was successfully performed. DOX was loaded into MWCNTs, released into the cytoplasm with high efficiency, and showed enhanced cytotoxicity against U87 human glioblastoma cells. These results demonstrated the potential of using magnetic nanocarriers for targeted delivery of DOX for cancer treatment.

Magnetic NPs incorporated into CNTs can be used as both an imaging process for cancer diagnosis and a drug delivery system for cancer treatment. Wu et $\mathrm{al}^{30}$ synthesized MWCNTs/cobalt ferrite $\left(\mathrm{CoFe}_{2} \mathrm{O}_{4}\right)$ magnetic hybrids using a solvothermal method. DOX-loaded magnetic hybrids showed a notable cytotoxicity in HeLa cancer cells following the intracellular release of DOX. The magnetic hybrids showed a high $\mathrm{T} 2$ relaxivity of $152.8 \mathrm{Fe} \mathrm{mM}^{-1} \mathrm{~s}^{-1}$ in aqueous solutions and significant negative contrast enhancement. Peci et $\mathrm{al}^{31}$ proposed functionalized magnetic nanotubes, which act as both a structure for targeted cancer treatment and a contrast agent for magnetic resonance imaging (MRI). To functionalize the CNTs, iron NPs were loaded into MWCNTs, and functionalized gadolinium $(\mathrm{Gd})$, which is used as a contrast agent for MRI, was added to the sidewalls of the MWCNTs. The heating functionality of Gd-doped magnetic CNTs was confirmed under a specific magnetic field. Their results indicated that functionalized CNTs (f-CNTs) have high potential as both MRI agents for cancer diagnosis and anticancer drug delivery systems for chemotherapy.

Chen et $\mathrm{al}^{32}$ investigated the loading of a different anticancer agent, EPI on carboxylated MWCNTs (c-MWCNTs). Because of the high surface area and hydrogen bonding interactions, the adsorption efficiency of c-MWCNTs was higher and more stable than those of unmodified MWCNTs and SWCNTs, and their drug-loading capacity was superior to that of MWCNTs. Increasing the $\mathrm{pH}$ enhanced the adsorption capacity of EPI on c-MWCNTs. However, in vitro and in vivo analysis of c-MWCNTs was not conducted.

Another aromatic molecule, DAU, has been applied as an anticancer agent. Taghdisi et al loaded DAU into SWCNTs functionalized with an sgc8c aptamer, which is a three-dimensional single-stranded DNA structure capable of targeting the leukemia biomarker protein, tyrosine kinase- $7 .{ }^{33}$ 
They achieved a high loading efficiency of $157 \%(\mathrm{w} / \mathrm{w})$ and showed a similar $\mathrm{pH}$-dependent release profile as DOX. At an equivalent DAU concentration, their system showed higher uptake and selectivity toward the target cell line (Molt-4) than the nontarget cell line (U266) compared to free DAU. From the results, it was observed that their new system presented a potential to reduce cytotoxic effects of DAU by selective delivery and controllable release of this drug to tumor cells.

\section{CNTs as Pt-based drug carriers}

Pt-based compounds have been studied as a class of effective anticancer agents. ${ }^{34}$ They kill cancer cells by chelating DNA and forming adducts that affect key cellular processes, such as transcription and replication, and trigger apoptosis. ${ }^{35,36}$ Inert $\mathrm{Pt}(\mathrm{IV})$ prodrugs and the combination between Pt(II) drugs and drug carriers have been widely studied. ${ }^{37-40}$

$\mathrm{Pt}(\mathrm{IV})$-conjugated CNTs were constructed to effectively deliver cisplatin (cis-dichlorodiammineplatinum, CDDP). ${ }^{41-48}$ Dhar et $\mathrm{al}^{41}$ developed amine-functionalized SWCNTs (SWCNTs-phospholipid-PEG-NH ${ }_{2}$ ) as a "longboat delivery system" for Pt-based CDDP. A complex of folate and CDDP was linked to amide bonds of SWCNTs to comprise the "longboat", which was internalized into cancer cells by endocytosis. Next, CDDP release and subsequent interactions between the nucleus and CDDP progressed. Tripisciano et $\mathrm{al}^{42}$ also evaluated CDDP-embedded SWCNTs using a wet chemical approach. The in vitro release profile of CDDPSWCNTs was smooth until 72 hours, and the maximum release percentage was $68 \%$. They demonstrated the inhibition of prostate cancer cell (PC-3 and DU145) growth by CDDP-SWCNTs.

Magnetic functionalization of CNTs combined with Pt-based anticancer agents show potential as magnetic carriers in drug delivery. Yang et $\mathrm{al}^{48}$ developed magnetic CNTs containing anticancer agents. Magnetite $\left(\mathrm{Fe}_{3} \mathrm{O}_{4}\right) \mathrm{NP}$ layers were synthesized on the inner surface of CNTs, and chemotherapeutic agents, such as 5-fluorouracil and cisplatin, were incorporated into the pores of the CNTs. Individualized CNTs were non-covalently functionalized by phospholipids with a PEG moiety and FA terminal group to enhance drug delivery to cancer cells. Their magnetic CNTs were retained in the draining targeted lymph nodes for several days and continuously released chemotherapeutic drugs, enabling the selective killing of tumor cells. They also studied the lymphatic distribution of magnetic CNTs in vivo. ${ }^{49}$ They prepared magnetic MWCNTs functionalized with poly(acrylic acid), which were subcutaneously injected into mice. The degree of black staining of lymph nodes and the concentration of magnetic CNTs were found to be dose dependent. The injection of CNTs did not show local or systemic toxicity. Their results demonstrated the potential of using magnetic CNTs for diagnosing and treating cancer.

Another Pt anticancer agent, carboplatin (cisdiammine(1,1-cyclobutanedicarboxylato) Pt(II), CP) was conjugated to CNTs. ${ }^{50,51}$ Hampel et $\mathrm{al}^{50}$ reported the incorporation of CP into MWCNTs. For this, CP was filled using a wet chemical approach based on capillary force after opening the CNTs. CP incorporation into the CNTs was confirmed by electron energy loss spectroscopy and X-ray photoelectron spectroscopy. In in vitro analysis, CP-MWCNTs inhibited the growth of urinary bladder cancer cells, whereas unfilled MWCNTs had a minimal effect on cancer cell growth.

\section{CNTs as antimicrotubule carriers}

During mitosis, microtubules assemble into mitotic spindles that distribute chromosomes to opposite poles of a dividing cell. Thus, given their essential roles in cell division and mitosis, microtubules are pharmaceutically validated targets for anticancer chemotherapy. ${ }^{52}$ Among antimicrotubules, paclitaxel (PTX) and docetaxel (DTX) have been widely studied. ${ }^{53-63}$

Arya et $\mathrm{al}^{53}$ reported that SWCNTs increase PTX activity against lung cancer by reactive-oxygen-species-dependent synergy between CNTs and PTX. They confirmed the efficacy on A549 and NCI-H460 cell lines. In a similar study, Zhang et $\mathrm{al}^{54}$ described the synergism between CNTs and PTX on ovarian cancer. They reported that PTX-conjugated SWCNTs sensitized human ovarian cancer OVCAR3 cells and resulted in higher cell death. In their study, SWCNTs showed two different functions as molecular carriers and chemosensitizers, and co-exposure of SWCNTs and chemotherapeutic drugs might thus be a promising approach to improve cancer treatment.

The poor water solubility of PTX resulted in the use of Cremophor EL in commercialized products such as Taxol ${ }^{\circledR}$. However, because Cremophor EL is toxic, studies have been conducted to identify alternatives. Sobhani et al ${ }^{56}$ proposed hyperbranched poly(citric acid) (PCA)-functionalized MWCNTs with high hydrophilicity and the conjugation of PTX with PCA-MWCNT-g-PCA. In cytotoxicity studies using A549 and SKOV3 cell lines, MWCNT-g-PCA-PTX showed a greater cytotoxic effect than the free drug over a shorter incubation time. These results presented potential of their system for cancer chemotherapy. 
Because the actual circulation time of Taxol ${ }^{\circledR}$ is very short, the coating of nanocarriers (eg, liposomes) using hydrophilic polymers such as PEG has been evaluated as a strategy for prolonging the circulation of nanocarrier-entrapped molecules in the blood. The circulation time of PTX was increased by PEG conjugation (PEGylation).$^{57}$ Liu et al ${ }^{58}$ reported chemically functionalized SWCNTs conjugated with PTX via branched $\mathrm{PEG}$ chains as a new prospect in tumor-targeted accumulation with low toxicity. In in vivo experiments, the blood circulation time of PTX-SWCNTs was longer and PTX uptake into the tumor as PTX-SWCNTs was tenfold higher than clinical $\mathrm{Taxol}^{\circledR}$ in a murine $4 \mathrm{~T} 1$ breast cancer model. These results showed that PTX-SWCNTs have high efficacy in suppressing tumor growth. Similar to the findings for anticancer activity, Lay et a ${ }^{59}$ found that the growth of MCF-7 cancer cells and HeLa cells was suppressed by PEGylated SWCNTs and MWCNTs with PTX.

In addition to PTX, Wang et a $l^{63}$ conjugated DTX, which has lower side effects than PTX, for breast and lung cancer treatment with Asn-Gly-Arg (NGR)-linked SWCNTs. DTX-NGR-SWCNTs showed higher suppression of tumor growth than DTX in PC-3 in vitro culture and murine S180 mouse cancer model. The tumor volumes in the mice were decreased considerably under near infrared (NIR) radiation compared to those in the control group. Based on their results, DTX-NGR-SWCNT drug delivery systems show potential for effective cancer therapy with minimal side effects.

Many molecule drugs have been functionalized to CNTs to enhance the therapeutic efficacy. The cellular uptake and intracellular distribution of CNT-drug complexes have been systematically studied. In addition, in vitro studies to determine the potential of CNT-drug complexes as drug delivery carriers and in vivo studies have supported the potential of CNT-based drug delivery systems. A few complexes were compared to their clinically available counterparts and showed potential for use in cancer therapy.

\section{CNTs as carriers for gene therapy}

Gene therapy aims to treat diseased cells by eliminating the cause of the disease using genetic materials. The therapeutic effects of successful gene therapy have been exploited in next-generation disease-modifying medical interventions, whereby a wide range of therapeutically active nucleic acids, including plasmid DNA (pDNA), small-interfering RNA (siRNA), antisense oligodeoxynucleotides (ODNs), and aptamers, have been used to manipulate gene expression at the posttranscriptional or translational levels. ${ }^{64-96}$ In gene therapy, the most important and difficult goal is to deliver genes to target cells across cellular barriers. This is challenging because of the hydrophilicity and large molecular size of genes. Therefore, it is necessary to employ viral or nonviral vectors to deliver the gene and internalize it into the cell. Although nonviral vectors including CNTs are less efficient than viral vectors and their life cycles are shorter than viral vectors, nonviral vectors are relatively safe and can deliver genes without size limitation. ${ }^{97,98}$ In this section, we focus on the applications of CNT-based vectors for cancer treatment using gene therapy.

\section{CNTs as pDNA carriers}

Plasmids are fragments of double-stranded DNA that are separated from the chromosomal DNA and can replicate independently of chromosomal DNA. Since the 1970s, they have been used as tools for genetic engineering. Plasmids are known as vector DNA because they are typically used to carry genes. Various f-CNTs have been studied to deliver pDNA using amine groups, polyethyleneimines (PEIs), polyamidoamine hybrids, cationic glycopolymers, and ethylenediamine.

Pantarotto et $\mathrm{al}^{64}$ prepared ammonium-functionalized SWCNTs with pDNA. Their complexes were internalized into mammalian cells and showed low cytotoxicity. The gene expression level by f-CNT-based DNA delivery was tenfold higher than for DNA alone. In addition, Gao et $\mathrm{a}^{65}$ reported that amino-functionalized MWCNTs $\left(\mathrm{NH}_{2}-\mathrm{MWCNTs}\right)$ can interact with pDNA and they delivered the green fluorescence protein gene into cultured human cells. These results demonstrated the potential of pDNA delivery systems for various therapies.

Singh et $\mathrm{al}^{66}{ }^{6}$ investigated the optimization of f-CNTs as gene delivery vehicles, including ammonium-functionalized MWCNTs (MWCNTs- $\mathrm{NH}_{3}^{+}, \mathrm{SWCNTs}-\mathrm{NH}_{3}^{+}$) and lysine-functionalized SWCNTs (SWCNTs-lysine- $-\mathrm{NH}_{3}^{+}$), with pDNA. Based on their results, nanotube surface area and charge density were critical parameters that determined the interaction and electrostatic complex formation between f-CNTs and DNA. Experiments using a mammalian cell line showed that all three f-CNTs upregulated gene expression markers to a greater extent than naked DNA did. They found that differences in gene expression levels were correlated with the structural and biophysical data obtained for the f-CNT. Their study was the first investigation into the physiochemical interactions between cationic f-CNTs and DNA.

Liu et $a l^{67}$ functionalized MWCNTs with CS-FA NPs through an ionotropic gelation process. Next, they investigated the effects of the length and surface functionalization of 
CNTs with CS-FA NPs on cytotoxicity and gene transfection efficiency. Although shorter MWCNTs showed higher gene transfection ability than longer CNTs, they were also more cytotoxic. In addition, the CS-FA-NP-functionalized MWCNTs (MWCNTs-CS-FA-NPs) showed increased transfection efficiency and decreased cytotoxicity. Under optimal conditions, the plasmid with EGFP (pEGFP)-N1 transfection efficiency of MWCNTs-CS-FA-NPs was 1.5-fold higher than that of non-functionalized MWCNTs; they did not decrease cell viability up to a concentration of $250 \mu \mathrm{g} \mathrm{mL}^{-1}$.

Behnam et $\mathrm{al}^{68}$ functionalized SWCNTs via non-covalent bonds with various types of PEIs. All PEI-functionalized CNTs showed good stability and dispersion ability in aqueous solution. In a pDNA condensing test, f-CNTs were sufficiently potent as effective gene delivery agents, even at low nitrogen to phosphate ratios. The transfection efficiency of PEI-functionalized CNTs was up to 19-fold higher than that of underivatized PEIs. PEI-functionalized CNTs were also effective gene delivery vectors following in vivo vein injection in mice. Their results revealed the potential of $\mathrm{f}-\mathrm{CNT}$ in gene delivery.

Karmakar et $\mathrm{l}^{72}$ proposed ethylenediamine-functionalized SWCNTs using the oncogene suppressor p53 gene for breast cancer treatment. Developed functionalized SWCNTs (f-SWCNTs)-p53 complexes were tested using MCF-7 breast cancer cells at a complex concentration of $20 \mu \mathrm{g} \mathrm{mL}^{-1}$ for 24 hours, 48 hours, and 72 hours. A large percentage of the cells $(\sim 40 \%)$ were dead after 72 hours of exposure to f-SWCNTs-p53, which was fourfold higher than those for the control, p53, or f-SWCNTs. Caspase-3 activity, which indicates induced apoptosis, was also significantly increased following treatment with the f-SWCNTs-p53 complex. Their results demonstrated the potential of f-CNTs for targeted apoptosis induction gene therapy.

\section{CNTs as siRNA carriers}

Recently, gene silencing using siRNA has been evaluated as gene therapy. This approach increased the efficiency of treating various diseases, including cancers. siRNA can be conjugated to f-CNTs through a disulfide linker, and f-CNT complexes can induce silencing and death of targeted cells. ${ }^{84}$

Wang et $\mathrm{al}^{76}$ applied f-SWCNTs to carry siRNA into K562 cells to inhibit the production of cylinA2, which plays a critical role in DNA replication, transcription, and cell cycle regulation. They showed that suppression of cyclinA(2) expression using siRNA-CNTs inhibited cell proliferation and apoptosis promotion, serving as a therapeutic target.
Their results may be applied as a useful therapeutic strategy for chronic myelogenous leukemia cells. Varkouhi et al ${ }^{77}$ investigated cationically functionalized CNTs with polyethylene imines or pyridinium for siRNA delivery. They prepared complexes using CNTs and siRNA that showed 10\%-30\% silencing activity and 10\%-60\% cytotoxicity.

Podesta et $\mathrm{al}^{78}$ studied cytotoxicity and tumor suppression by complexes of siRNA and amino-functionalized MWCNTs $\left(\mathrm{MWCNTs}-\mathrm{NH}_{3}^{+}\right)$both in vitro and in vivo. Their complexes showed significant cytotoxic activities in vitro, delayed tumor growth, and increased the survival of xenograft-bearing animals. Zhang et al ${ }^{79}$ conjugated f-SWCNTs with telomerase reverse transcriptase siRNA to suppress tumor growth. In an in vitro study using murine tumor cells, mammalian telomerase reverse transcriptase expression was suppressed and growth arrest was observed. Moreover, the tumor was reduced in an in vivo study using a mouse model.

Bartholomeusz et al ${ }^{89}$ fabricated non-covalent complexes of unmodified siRNA and pristine SWCNTs. When complexes containing siRNA targeted to hypoxia inducible factor 1 alpha (HIF-1 $\alpha$ ) were added to the culture media, cellular HIF-1 $\alpha$ activity was strongly inhibited. The biological response observed for the complexes was detected in various types of cancer cells. Moreover, in MiaPaCa-2/HRE tumorbearing mice, SWCNTs-HIF-1 $\alpha$-siRNA complexes significantly inhibited the activity of tumor HIF-1 $\alpha$ associated with resistance to therapy. These results indicate that SWCNTssiRNA complexes can be used as therapeutic agents.

\section{CNTs as ODN carriers}

Antisense therapy, an important technique for curing tumors or genetic disorders using antisense oligodeoxynucleotides (ASODNs), which can bind to the start location of mRNA translation inside of cells, blocks the translation of target mRNA into protein and then inhibits targeted gene expression at the protein level..$^{93,94}$

Jia et $\mathrm{al}^{93}$ studied double functionalization of an MWCNT delivery system containing ASODNs as a therapeutic gene and semiconductor quantum dots (CdTe) as fluorescent labeling probes (Figure 3). The MWCNT-PEI-ASODNs-CdTe composites showed an ODN delivery efficiency of $95 \%$ in human cervical cancer (HeLa) cells and induced much higher cellular apoptosis than PEI-ASODNs or ASODNs alone. Pan et $\mathrm{al}^{94}$ conjugated ASODNs with polyamidoamine dendrimer-modified MWCNTs to improve the delivery efficiency of genes. These complexes exhibited high transfection efficiency and inhibition of human breast cancer cells 
A
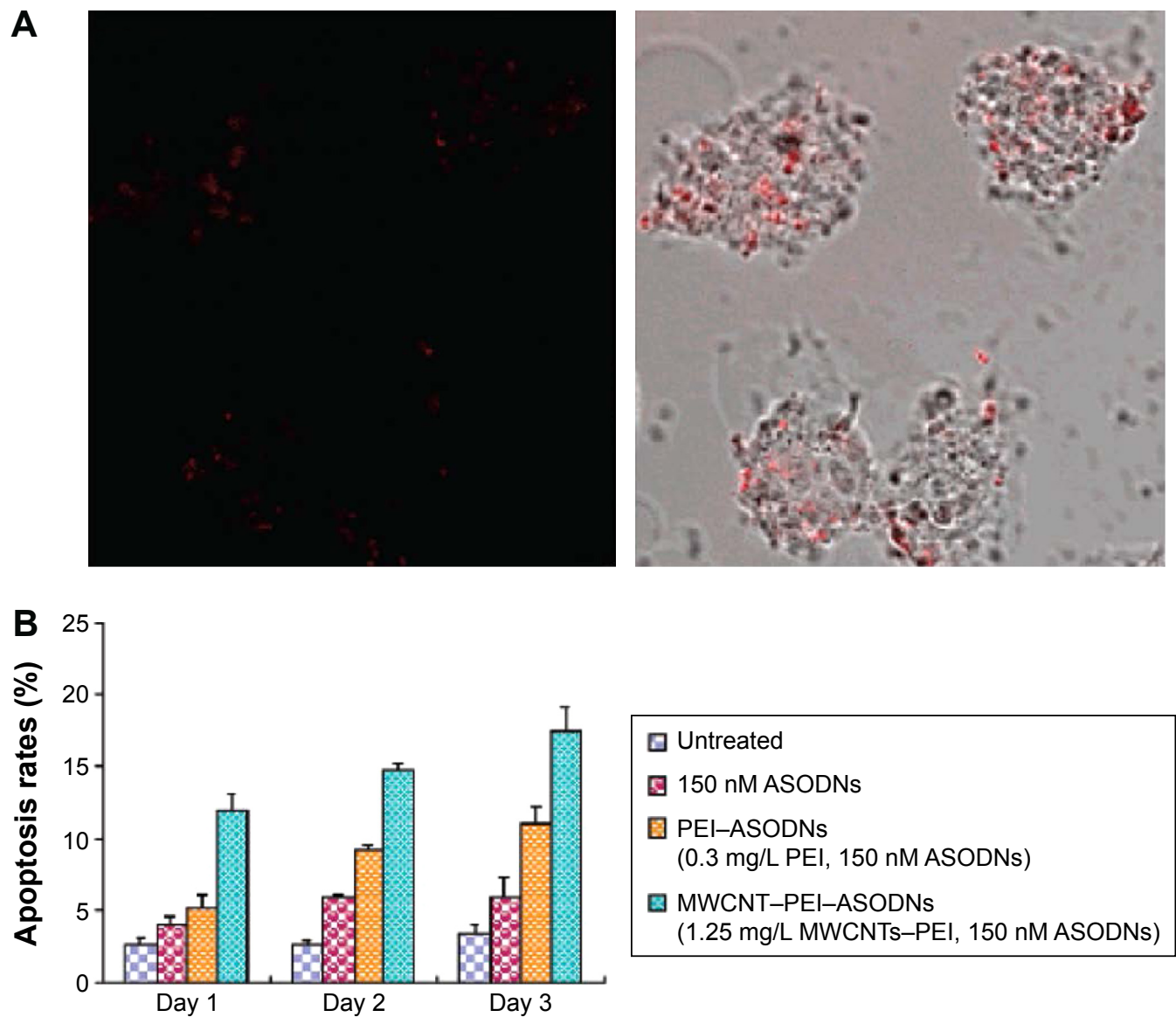

Figure 3 Apoptosis of HeLa cells by ASODNs treatments.

Notes: (A) Confocal fluorescence image of HeLa cells taken 24 hours after I-hour incubation with MWCNT-PEI-ASODN-CdTe at $37^{\circ} \mathrm{C}$ (left) and merged image (right). (B) Flow cytometric analysis. After culturing the cells in the presence of naked ASODNs, PEI-ASODNs, and MWCNT-PEI-ASODNs, cells were harvested, washed in PBS, fixed in $1 \%$ paraformaldehyde, permeabilized with $96 \%$ ethanol, RNase treated, and then stained with propidium iodide $(50 \mu g / \mathrm{mL})$. The cells were analyzed at $24-$ hour intervals for a period of 72 hours. Reprinted with permission from Jia N, Lian Q, Shen H, Wang C, Li X, Yang Z. Intracellular delivery of quantum dots tagged antisense oligodeoxynucleotides by functionalized multiwalled carbon nanotubes. Nano Lett. 2007;7(10):2976-2980.93 Copyright 2007 American Chemical Society.

Abbreviations: ASODNs, antisense oligodeoxynucleotides; MWCNTs, multiwalled carbon nanotubes; PBS, phosphate-buffered saline; PEI, polyethyleneimine.

(MCF-7 and MDA-MB-435) and liver cancer cells (HepG2). Therefore, functionalized MWCNTs showed a potential for biological delivery applications and gene therapy.

\section{CNTs as aptamer carriers}

The delivery of DNA/RNA aptamers by CNTs may be an effective gene therapy technique. Aptamers are RNA- or DNA-based single-stranded short ODNs that can recognize their intracellular targets based on shape matching. Because they can disrupt protein-protein interactions, aptamers can inhibit intracellular pathways and show potential in various therapies. ${ }^{95}$ Van den Bossche et a ${ }^{95}$ grafted aptamers to carboxylated CNTs for use as a vector system to facilitate translocation into the cytosol of different cell types independently of receptor-mediated uptake. Their composites showed efficient intracellular delivery, suggesting the potential for therapeutic applications of biologically active aptamers.
Mohammadi et a ${ }^{99}$ synthesized an RNA aptamer against epithelial cell adhesion molecule (EpCAM) (EpDT3) and attached the aptamer to piperazine-PEI-conjugated SWCNTs. The DNA transfection efficiency and siRNA delivery activity of SWCNTs-PEI-piperazine were investigated against upregulated BCL91, which is related to colorectal and breast cancers. The complexes specifically induced apoptosis by $>20 \%$ in EpCAM-positive cells compared to that in EpCAM-negative cells. A decrease in BCL91 protein level was observed in EpCAM-positive cells. These results indicate the targeted silencing activity of the complex.

For several decades, a wide range of therapeutically active nucleic acids such as pDNA, siRNA, ODNs, and aptamers have been studied to manipulate gene expression at the posttranscriptional or translational level. Various gene therapeutic methods using CNTs have been reported and showed potential in biological delivery applications and gene therapy. 


\section{CNTs as carriers of proteins and immunoactive components}

CNTs have also been applied to deliver proteins for cancer treatment. For example, streptavidin, a protein purified from the bacterium Streptomyces avidinii, shows anticancer activity. ${ }^{100}$ However, it cannot penetrate the cells because of its large molecular weight $(\sim 60 \mathrm{kDa})$. Shi Kam et al ${ }^{101}$ conjugated streptavidin to an SWCNT-biotin transporter to internalize streptavidin into promyelocytic leukemia (HL60) cells and human T-cells (Jurkat) through the endocytosis pathway (Figure 4). The uptake pathway of the conjugates was consistent with endocytosis, suggesting that SWCNTs can be utilized as transporters for various cargos.

Parra et al $^{102}$ prepared four f-CNT complexes (CNT-bovine serum albumin [BSA]-AZc6) covalently coupled with azoxystrobin derivative, hapten AZc6, and BSA. For the antibody response test, New Zealand rabbits and BALB/c mice were immunized with BSA-AZc6 alone and with the four CNTBSA-AZc6 constructs, both with and without Freund's adjuvant. Immunization resulted in enhanced titers and excellent affinities for azoxystrobin. Strong IgG responses were observed for the adjuvant absence condition, supporting the self-adjuvant capability of CNTs. Among the four types of CNT-BSA-AZc6 constructs, the short and thick constructs showed the best antibody responses under all tested conditions. Thus, the vaccine efficiency of antigens was improved by f-CNTs.

Weng et $\mathrm{al}^{103}$ proposed recombined ricin A chain (RTA)induced selective destruction of tumor cells through CNT transporters. The conjugate of MWCNTs and toxin protein RTA was translocated into the cytoplasm of various cell lines, which induced cell death. Cell death rates for L-929, HeLa, HL7702, MCF-7, and COS-7 cells caused by RTA-MWCNT conjugates were threefold higher than those achieved by RTA alone. Particularly, the cell mortality of HeLa cells reached $\sim 75 \%$. Selective destruction of certain breast cancer cells was observed by coupling MWCNT-RTA-human epidermal growth factor receptor 2 (HER2). These results indicate that the transporting capability of CNTs with functional proteins represents a new method of cancer therapy.

Li et al $^{104}$ synthesized MWCNT-CS NP hybrid through an in situ ionotropic gelation process. The CS NP was tethered to the MWCNT surface with high density and uniform coverage under optimal conditions, and the MWCNT_CS NP hybrids showed good dispersibility and stability in aqueous solutions. A cytotoxicity test using HeLa cells demonstrated that the MWCNT-CS NP hybrids were biocompatible at concentrations up to $100 \mu \mathrm{g} \mathrm{mL}^{-1}$. A protein immobilization test using BSA showed that the MWCNT-CS NP hybrids improved the immobilization efficiency by 0.8 -fold and decreased cellular toxicity by $\sim 50 \%$ compared to c-MWCNTs. These results indicate the potential utilization of the hybrids as protein carriers.

Sanz et al ${ }^{105}$ prepared SWCNT complexes with amphiphilic polypeptides and characterized the adsorption of natural proteins onto the complexes. Based on the properties of the SWCNT-polypeptide complexes, a model for predicting the SWCNT adsorption and dispersion properties
A

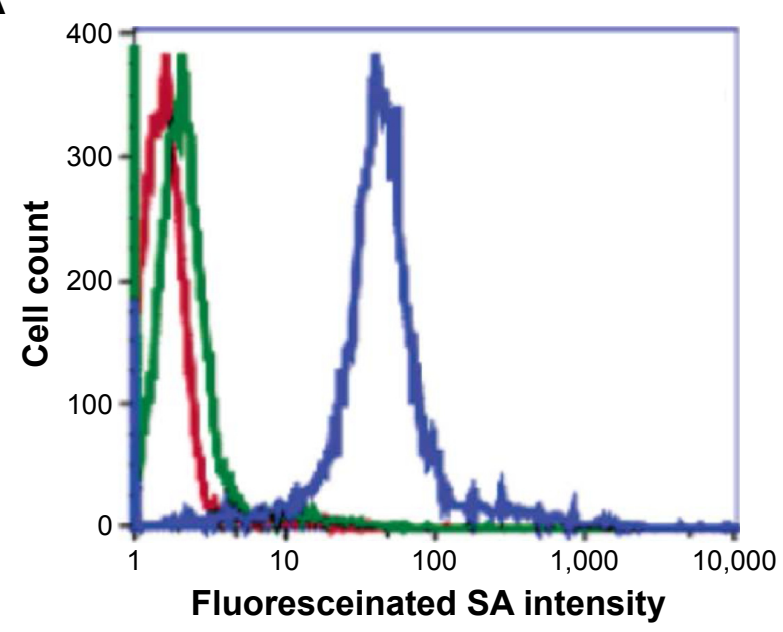

B
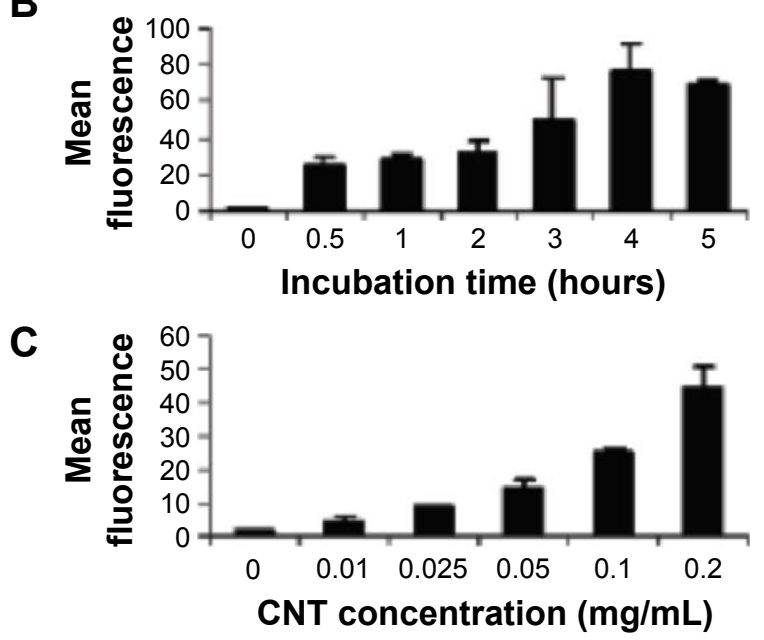

Figure 4 Flow cytometry data.

Notes: (A) Fluorescence histogram for untreated cells (red curve), cells after I-hour incubation in a solution containing Alexa Fluor-labeled SA only (green curve) and after I-hour incubation in a solution of SWCNT-biotin-SA (blue curve). (B) Mean green fluorescence of cells vs time of incubation in four SWCNTs (0.05 mg/mL). (C) Mean green fluorescence of cells vs concentration of SWCNT-biotin-SA after I-hour incubation. Reprinted with permission from Shi Kam NW, Jessop TC, Wender PA, Dai H. Nanotube molecular transporters: internalization of carbon nanotube-protein conjugates into Mammalian cells. J Am Chem Soc. 2004; I26(22):6850-685I. ${ }^{101}$ Copyright 2004 American Chemical Society.

Abbreviations: CNTs, carbon nanotubes; SA, streptavidin; SWCNTs, single-walled CNTs. 
of natural proteins was developed. This model could predict natural protein adsorption onto SWCNTs and enable the design of preparation methods of SWCNT-protein complexes. In addition, the utilization of cationic-designed amphiphilic polypeptides to disperse SWCNTs was applied for DNA binding to CNTs. Their results suggested new procedures for using SWCNTs as protein and DNA carriers.

Immunotherapy is another possible tool for use in cancer therapy. As the biomedical applications of immunotherapy have expanded, antitumor immunotherapy using CNTs has been evaluated. McDevitt et $\mathrm{al}^{106}$ attached tumor-specific monoclonal antibodies to SWCNTs to target lymphoma and used a metal ion chelator to carry and deliver a radioactive metal ion, which was attached to a fluorescent chromophore to report its location. Ruggiero et $\mathrm{al}^{107}$ attached the tumor neovascular-targeting antibody E4G10 to SWCNTs via radiometal-ion chelates. The specific activity and blood compartment clearance kinetics of these complexes were significantly improved compared to antibody alone. In a murine xenograft model of human colon adenocarcinoma, the complexes reduced tumor volume and improved median survival relative to in controls. Meng et $\mathrm{al}^{108}$ increased the general activity of the host immune system using oxidized MWCNTs in a hepatocarcinoma tumor-bearing mice model. Subcutaneous-injected CNTs induced activation of the complement system, promoted the production of inflammatory cytokines, and stimulated phagocytosis of macrophages, leading to the inhibition of tumor growth. Their results demonstrated that modified CNTs can induce anticancer activity by provoking an immune response against the tumor.

Glioma (brain tumor) cells secrete immunosuppressive cytokines such as transforming growth factor- $\beta$, prostaglandins E, and interleukin (IL)-10 and can evade the host immune system. ${ }^{109,110}$ Therefore, successful treatment is difficult using conventional chemotherapy. Van Handel et $\mathrm{al}^{111}$ proposed an immunotherapy approach using MWCNTs based on the preferential uptake of CNTs by macrophages compared to that by glioma cells. Injected MWCNTs increased the influx of macrophages into glioma cells and increased the tumor cytokine level (IL-10) in time- and dose-dependent manners, but did not show significant toxicity in normal or tumorbearing mice. These results suggest that immune modulation using CNTs is a possible strategy for brain tumor therapy.

Recently, Fadel et al ${ }^{112}$ proposed a CNT-polymer composite that can act as an artificial antigen-presenting cell (APC) to efficiently expand T-cells. Antigens were attached to bundled CNTs, and this CNT complex was combined with polymer NPs containing magnetite and the T-cell growth factor
IL-2. A proliferation of T-cell was progressed at least 1,000fold less than IL-2 concentration than the conventional culture condition, and the obtained T-cells suppressed tumor growth in a B16 mouse melanoma model. Their results demonstrate the potential of expanding T-cells in cancer immunotherapy.

Fan et $\mathrm{al}^{113}$ studied the systemic antitumor response following intracerebral delivery of $\mathrm{CpG}$ with CNTs. In a melanoma mouse model, they confirmed that intracranial CNT$\mathrm{CpG}$ therapy inhibited not only the growth of brain tumors but also subcutaneous melanomas. Based on the results, they suggested that intracerebral CNT-CpG therapy could be used to treat not only gliomas but also metastatic brain tumors. In a similar study, Zhao et $\mathrm{al}^{114}$ evaluated CNTs as a CpG delivery vehicle in brain tumor models. CNTs enhanced $\mathrm{CpG}$ uptake by tumor-associated phagocytic cells and resulted in their activation both in vitro and in vivo. Single injection with a low dose of CNT-CpG complexes eradicated intracranial GL261 gliomas in half of tumor-bearing mice via activation of NK and CD8 cells. These findings demonstrated that CNTs could improve $\mathrm{CpG}$ uptake into tumor-associated inflammatory cells without toxicity and lead to a robust antitumor response. Recently, Ouyang et $\mathrm{l}^{115}$ proposed an SWCNT complex that increased the immunotherapeutic efficacy of $\mathrm{CpG}$ ODNs. SWCNT-CpG was combined with temozolomide and evaluated in an invasive mouse glioma model (K-Luc) that better recapitulates human disease. SWCNT- $\mathrm{CpG}$ improved the survival of mice, and the efficacy of SWCNTs/CpG was enhanced when combined with temozolomide. This improved antitumor efficacy was correlated with increased tumorspecific cytotoxic activity in splenocytes.

Villa et al ${ }^{116}$ studied the potential of using SWCNTs as antigen carriers to improve immune responses to peptides. They covalently attached a large number of peptides $(0.4 \mathrm{mmol} / \mathrm{g})$ to solubilized SWCNTs and internalized them into professional APCs (dendritic cells and macrophages) within minutes in vitro. In immunization tests using BALB/c mice, a mixture of the SWCNT-peptide constructs and immunological adjuvants induced specific $\mathrm{IgG}$ responses against the peptide, while the peptide alone or adjuvant mixed peptide did not induce such a response. In addition, solubilized SWCNTs were nontoxic in vitro and antibody responses to SWCNTs were not detected in vivo. These results demonstrate that SWCNTs can deliver immunotherapeutic materials into APCs to induce humoral immune responses.

Sacchetti et al $^{117}$ studied ligands against regulatory T-cell $\left(\mathrm{T}_{\text {reg }}\right)$-specific receptors to drive selective internalization of PEG-modified SWCNTs (PEG-SWCNTs) into $\mathrm{T}_{\text {reg }}$ residing in the tumor microenvironment. They focused on the 
glucocorticoid-induced tumor necrosis factor receptor (TNFR)related receptor (GITR). In in vivo experiments, $\mathrm{PEG-SWCNTs}$ with GITR ligands targeted $\mathrm{T}_{\text {reg }}$ residing in B16 melanoma cells more efficiently than intratumor non- $\mathrm{T}_{\text {reg }}$ or splenic $\mathrm{T}_{\text {reg }}$. Moreover, PEG-SWCNTs with GITR ligands were internalized by $\mathrm{T}_{\text {reg }}$ through receptor-mediated endocytosis and transported into the cytoplasm/nucleus in vivo. These results provide a foundation for innovative immunotherapy against cancer.

Meng et $\mathrm{al}^{118}$ conjugated MWCNTs to tumor lysate protein to enhance the efficacy of immunotherapy employing a tumor cell vaccine. In an H22 liver cancer-bearing mouse model, the efficacy of tumor curing and the cellular antitumor immune reaction in the tumor lysate protein-conjugated CNTs were markedly improved. Remarkably, the observed antitumor immune response was relatively specific against the tumor intended for treatment.

CNTs have been studied as a protein delivery system in cancer therapy and as a tool for immunotherapy through the antibody delivery and the role of an artificial APC. These therapeutic modalities induce, enhance, or suppress the immune response. In this section, we have presented a series of studies demonstrating the potential of CNTs. These findings suggest that CNTs can be used to develop new antitumor immunotherapies.

\section{Photothermal and photodynamic therapies for cancer treatment}

PTT and PDT are two methods that can be utilized for cancer treatment and show noninvasiveness and minimal side effects compared to existing strategies including radiotherapy and chemotherapy (Figure 5). ${ }^{119}$ However, it has been difficult to identify materials that show both efficiency and biosafety. Because of the unique properties of CNTs that can generate singlet oxygens, which are cytotoxic, through photochemistry and generate significant amounts of heat upon excitation with NIR light, CNTs have been evaluated as candidate materials in PTT and PDT (a summary of CNTs as cancer therapeutic mediators described in this review is given in Table 2).

\section{PTT for cancer treatment}

CNTs can effectively absorb NIR light, and the absorbed NIR light transmits heat to the nanotubes. Therefore, when the optical coupling effect of light and CNTs is applied, external heat energy can be transmitted inside the body. ${ }^{120}$ This unique property of CNTs has been exploited as a method for killing cancer cells via thermal effects. ${ }^{121-134}$ The optical coupling of light with CNTs can be enhanced by the surface defects of CNTs based on the antenna theory, and nanotechnology induces intentional surface defects to increase nanotube heating. ${ }^{122}$ This electrophysical characteristic of the engineered CNTs including boron and nitrogen dopants (p-type dopants) to improve the thermal destruction performance of tumor cells.

Gannon et al ${ }^{121}$ discovered the heat release of SWCNTs in a radiofrequency (RF) field. They prepared functionalized, water-soluble SWCNTs using Kentera (a polyphenylene ethynylene-based polymer). Direct intratumoral injection of SWCNTs followed by an immediate RF field treatment was

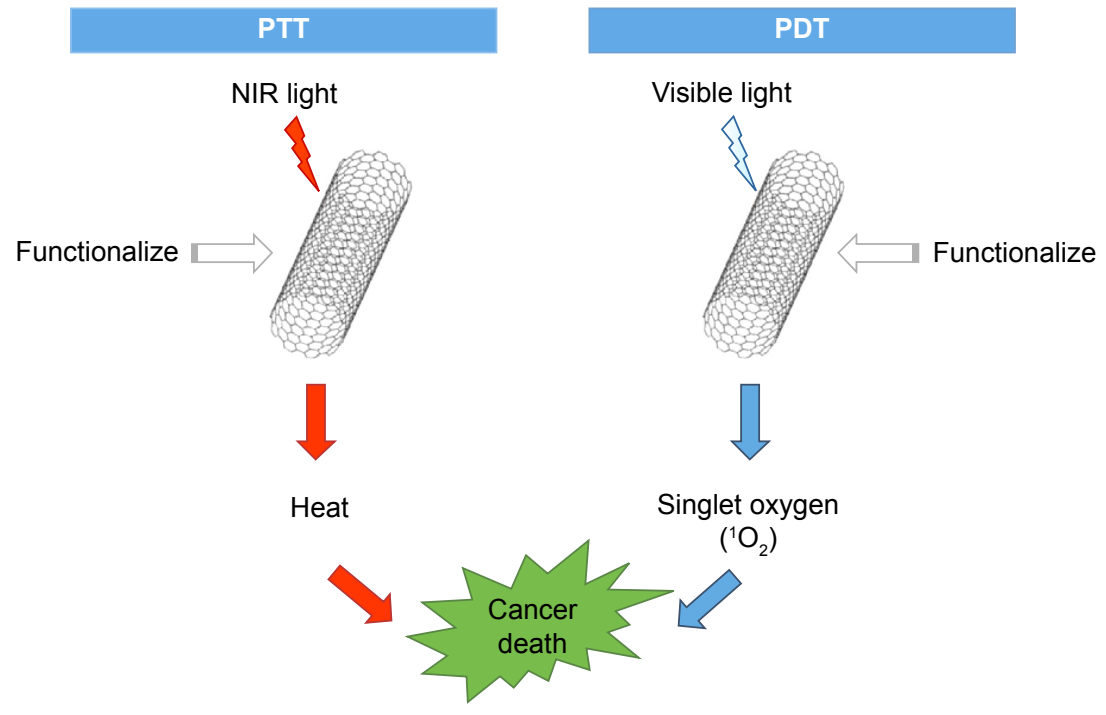

Figure 5 Processes of PTT and PDT using CNTs.

Abbreviations: CNTs, carbon nanotubes; NIR, near infrared; PDT, photodynamic therapy; PTT, photothermal therapy. 
Table 2 Summary of CNTs as cancer therapeutic mediators described in this review

\begin{tabular}{|c|c|c|c|c|}
\hline Category & CNT system & $\begin{array}{l}\text { Biological studies (in vitrol } \\
\text { in vivo) }\end{array}$ & Results & References \\
\hline \multirow[t]{11}{*}{ PTT } & SWCNTs & $\begin{array}{l}\text { In vivo: rabbits bearing hepatic VX2 } \\
\text { tumors }\end{array}$ & $\begin{array}{l}\text { SWCNT-treated tumors showed complete } \\
\text { necrosis, whereas control tumors injected } \\
\text { with the Kentera alone were completely } \\
\text { viable at the RF field }\end{array}$ & 121 \\
\hline & MWCNTs & In vitro: kidney cancer cells & $\begin{array}{l}\text { Wavelengths between } 700 \mathrm{~nm} \text { and } \mathrm{I}, 100 \mathrm{~nm} \\
\text { were most desirable to kill the tumor }\end{array}$ & 122 \\
\hline & SWCNTs & In vitro: EMT6 & $\begin{array}{l}\text { The combination of laser and SWCNTs } \\
\text { showed remarkable efficacy in the } \\
\text { suppression of breast cancer growth }\end{array}$ & 124 \\
\hline & f-SWCNTs (GC) & $\begin{array}{l}\text { In vitro: EMT6 } \\
\text { In vivo: mice bearing EMT6 tumors }\end{array}$ & $\begin{array}{l}\text { GC-SWCNTs with the laser showed a } \\
\text { remarkable tumor growth suppression and } \\
\text { long-term survival in many cases }\end{array}$ & 125 \\
\hline & f-MWCNTs (anti-GD2) & In vitro: stNB-VI & $\begin{array}{l}\text { stNB-VI cells were all found to undergo } \\
\text { necrosis, while non-GD2-expressing PCI2 } \\
\text { cells all remained viable }\end{array}$ & 126 \\
\hline & MWCNTs & $\begin{array}{l}\text { In vitro: RENCA } \\
\text { In vivo: mice bearing RENCA tumors }\end{array}$ & $\begin{array}{l}\text { Their treatment with } 100 \mu \mathrm{g} \text { of } \\
\text { MWCNT resulted in a durable remission } \\
\text { of }>3.5 \text { months in } 80 \% \text { of mice }\end{array}$ & 127 \\
\hline & MWCNTs & In vitro: EAC & $\begin{array}{l}95.2 \% \text { of EAC cells with the addition of } \\
\text { MWCNTs were dead after } 1.5 \text { minutes of } \\
\text { NIR irradiation }\end{array}$ & 128 \\
\hline & DNA-encased MWCNTs & $\begin{array}{l}\text { In vivo: mice bearing PC- } 3 \text { xenograft } \\
\text { tumors }\end{array}$ & $\begin{array}{l}\text { Tumors were completely eradicated in } \\
\text { all nude mice, while nonmalignant tissues } \\
\text { displayed no long-term damage by their } \\
\text { treatment }\end{array}$ & 129 \\
\hline & f-SWCNTs (HER2 lgY) & In vitro: SK-BR-3 & $\begin{array}{l}\text { SK-BR-3 cells (HER2 positive) and NIR } \\
\text { irradiation showed selective destruction of } \\
\text { complex-targeted breast cancer cells }\end{array}$ & 130 \\
\hline & SWCNTs & In vivo: mice bearing $K B$ tumors & $\begin{array}{l}\text { Tumors were completely destroyed in } \\
\text { mice, and recurrence of tumors was not } \\
\text { observed over } 6 \text { months }\end{array}$ & 131 \\
\hline & SWCNTs & In vivo: mice bearing SCCVII tumors & $\begin{array}{l}\text { SWCNTs kept the localization in the } \\
\text { tumors even } 3 \text { months after injection }\end{array}$ & 132 \\
\hline \multirow[t]{5}{*}{ PDT } & $\begin{array}{l}\text { f-SWCNTs (ZnMCPPc- } \\
\text { spermine) }\end{array}$ & In vitro: MCF-7 & $\begin{array}{l}\text { ZnMCPPc-spermine-SWCNTs resulted in } \\
95 \% \text { decrease in cell viability }\end{array}$ & 135 \\
\hline & f-SWCNTs (aptamer) & - & $\begin{array}{l}\text { A thrombin introduction using } \\
\text { AP-SWCNTs showed I3-fold enhancement } \\
\text { of SOG }\end{array}$ & 136 \\
\hline & f-SWCNTs (CS-Ce6) & In vitro: HeLa & $\begin{array}{l}\text { CS-Ce6-SWCNTs showed low dark toxicity } \\
\text { and efficient PDT efficacy to HeLa cells }\end{array}$ & 137 \\
\hline & $\begin{array}{l}\text { f-SWCNTs (distyryl-Bodipy } \\
\text { (PDT sensitizer)) }\end{array}$ & - & $\begin{array}{l}\text { The complex showed slightly lower activity } \\
\text { than the free compound }\end{array}$ & 139 \\
\hline & $\begin{array}{l}\text { f-MWCNTs (polyamidoamine } \\
\text { dendrimer modified) }\end{array}$ & In vitro: MGC-803 & $\begin{array}{l}\text { MWCNT complexes increased the } \\
\text { destruction of tumor cells after PDT } \\
\text { treatment at } 632 \mathrm{~nm} \text { wavelength }\end{array}$ & 140 \\
\hline \multirow[t]{3}{*}{ PTT + PDT } & f-SWCNTs (HMME-HA) & $\begin{array}{l}\text { In vitro: } \mathrm{BI} 6 \mathrm{FIO} \\
\text { In vivo: mice bearing BI6FI0 tumors }\end{array}$ & $\begin{array}{l}\text { The combination of PTT and PDT using the } \\
\text { complex showed higher therapeutic efficacy } \\
\text { of cancer treatment than PDT or PTT alone }\end{array}$ & 141 \\
\hline & f-SWCNTs (Ru) & $\begin{array}{l}\text { In vitro: HeLa } \\
\text { In vivo: mice bearing HeLa tumors }\end{array}$ & $\begin{array}{l}\text { In vitro and in vivo tumor ablation studies } \\
\text { showed an excellent treatment efficacy }\end{array}$ & 142 \\
\hline & f-MWCNTs (mTHPC) & In vitro: SKOV3 & $\begin{array}{l}\text { Cancer cytotoxicity correlated at the cell } \\
\text { level with the uptake of mTHPC-MWCNTs }\end{array}$ & 143 \\
\hline
\end{tabular}

Abbreviations: AP-SWCNTs, aptamers in SWCNTs; Ce6, chlorin 6; CS, chitosan; EAC, Ehrlich ascites carcinoma; f, functionalized; GC, glycated chitosan; HMME, hematoporphyrin monomethyl ether; HA, hyaluronic acid; mTHPC, m-tetrahydroxyphenylchlorin; MWCNTs, multiwalled carbon nanotubes; NIR, near infrared; PC-3, prostate cancer cell; PDT, photodynamic therapy; PTT, photothermal therapy; RF, radiofrequency; SOG, singlet oxygen generation; SWCNTs, single-walled carbon nanotubes; ZnMCPPc, zinc mono carboxy phenoxy phthalocyanine; GD2, disialoganglioside 2; Ru, ruthenium. 
conducted in rabbits with hepatic VX2 tumors. At 48 hours, SWCNT-treated tumors showed complete necrosis, whereas control tumors injected with Kentera alone (without CNTs) were completely viable at the RF field. SWCNT-injected tumors without RF treatment were also viable. Their results suggest that SWCNTs targeted to cancer cells allow noninvasive RF field treatments to produce lethal thermal injury to malignant cells.

Torti et al ${ }^{122}$ proposed a photo-ablative model using MWCNTs and NIR light to kill kidney cancer cells. They confirmed that an effective NIR coupling effect occurs at nanotube lengths exceeding half of the wavelength of the radiating NIR, as demonstrated by the antenna theory. This radiation increased the temperature of MWCNTs through induction processes, and then the generated heat from MWCNTs was transferred to the surrounding media to continue killing cancer cells at lower radiation doses. Their work showed that lengths between $700 \mathrm{~nm}$ and 1,100 nm were most desirable for killing the tumor.

Zhou et al ${ }^{123}$ utilized SWCNTs with a uniform size $(\sim 0.81 \mathrm{~nm})$ and a narrow absorption peak at $980 \mathrm{~nm}$ for selective PTT to kill cancer cells. Their SWCNTs were conjugated to FA, which can specifically bind to the tumor surface. The FA-SWCNT-targeted tumor cells were irradiated by a $980 \mathrm{~nm}$ laser. According to in vitro and in vivo experiments, FA-SWCNTs effectively improved the photothermal destruction of tumor cells while noticeably minimizing the photothermal destruction of nontargeted normal cells. In addition, they also proposed a therapy model with mitochondriatargeting SWCNTs. ${ }^{124}$ This model converted NIR energy into heat for selective destruction of target mitochondria, inducing mitochondrial depolarization, cytochrome c release, and caspase- 3 activation. The combination of laser and SWCNTs showed remarkable efficacy for suppressing breast cancer growth and complete tumor regression in some cases. They also developed an immunologically modified nanotube system using an immunoadjuvant, glycated chitosan (GC) and SWCNTs. ${ }^{125}$ Using GC-SWCNTs and the same laser system, they investigated the induced thermal and immunological effects of tumors in in vitro and in vivo environments. GC-SWCNTs combined with the laser showed remarkable tumor growth suppression in animal cancer models and resulted in complete tumor regression and long-term survival in many cases. These results revealed the possibility of selective local treatment with minimal side effects.

Wang et al ${ }^{126}$ conjugated disialoganglioside (GD2) monoclonal antibody (anti-GD2) to acidified MWCNTs to target GD2 overexpressed on the surface of neuroblastoma
stNB-V1 cells. To track the anti-GD2-bound MWCNTs, rhodamine $\mathrm{B}$ was labeled on carboxylated CNTs functionalized with and without anti-GD2. After incubation of antiGD2-conjugated MWCNTs with neuroblastoma cells and endocytosis by the cells, CNT-laden neuroblastoma cells were irradiated with an $808 \mathrm{~nm}$ NIR laser with two-step intensities. After the second laser exposure, stNB-V1 cells had all undergone necrosis, while all non-GD2-expressing PC-12 cells remained viable. Based on the results, MWCNTs bound with anti-GD2 showed a potential as a coupling agent for the PTT of neuroblastoma cells.

Burke et $\mathrm{al}^{127}$ used MWCNTs to generate heat in response to NIR light for the thermal destruction of kidney cancer in vitro and in vivo. They demonstrated the therapeutic effects of heat via heat-shock protein-reactive immunohistochemistry and magnetic resonance temperature mapping. They verified that MWCNTs ablated tumors at a low laser power $\left(3 \mathrm{~W} / \mathrm{cm}^{2}\right)$ and short treatment time $(30 \mathrm{~s})$, with minimal local damage. These treatment parameters resulted in durable remission of $>3.5$ months in $80 \%$ of mice with $100 \mu \mathrm{g}$ of MWCNT treatment.

Burlaka et al ${ }^{128}$ concluded that the use of MWCNTs with NIR light is a promising candidate for anticancer therapy. They also studied the hyperthermic effect of MWCNTs stimulated with NIR irradiation for anticancer therapy. They used the NIR irradiation to destroy Ehrlich ascites carcinoma (EAC) cells, and $95.2 \%$ of EAC cells treated with MWCNTs were dead after 1.5 minutes of NIR irradiation. Under cell death conditions, the ablation temperature was $\sim 50^{\circ} \mathrm{C}$. Their results showed that the addition of MWCNTs to an EAC cell suspension caused photothermal destruction of cells over a short NIR exposure time.

Ghosh et al ${ }^{129}$ showed that DNA encasement increases heat emission by NIR irradiation of MWCNTs and DNAencased MWCNTs can be utilized to destroy tumors in vivo. Using NIR irradiation, heat was generated with a linear relationship with laser power and irradiation time. At increasing temperatures, the performance of DNA-encased MWCNTs was threefold higher than that of non-encased MWCNTs. Treatment of PC-3 xenograft tumors using intratumoral injection of MWCNTs ( $100 \mu \mathrm{L}$ of a $500 \mu \mathrm{g} / \mathrm{mL}$ solution) followed by laser irradiation $\left(1,064 \mathrm{~nm}, 2.5 \mathrm{~W} / \mathrm{cm}^{2}\right)$ completely eradicated PC-3 tumors in all nude mice. However, tumors treated with only MWCNT injection or laser irradiation grew similarly to nontreated control tumors. In addition, nonmalignant tissues displayed no long-term damage following treatment. Their results showed that DNA-encased MWCNTs were more efficient for converting NIR irradiation 
into heat and may be safely used for the selective ablation of malignant tissue.

Xiao et al $^{130}$ constructed an HER2 IgY-SWCNT complex and studied the detection and selective destruction of cancer cells using the complex in an in vitro model. Raman signals for cancer detection were gathered using Raman spectrometers at a $785 \mathrm{~nm}$ laser excitation, and NIR irradiation was performed at $808 \mathrm{~nm}$ with $5 \mathrm{~W} / \mathrm{cm}^{2}$ for 2 minutes. Collected Raman signals revealed the selectivity of the complex-treated SK-BR-3 cells (HER2-positive), and NIR irradiation showed selective destruction of complex-targeted breast cancer cells without damaging receptor-free cells. Therefore, a combination of the intrinsic properties of SWCNTs and IgY antibody offered a new possibility for cancer detection and therapy.

Moon et $\mathrm{a}^{131}$ studied the in vivo obliteration of solid malignant tumors by combined treatment with SWCNTs and NIR irradiation (Figure 6). The tumors were completely destroyed in mice in the photothermal treatment group, and harmful side effects or tumor recurrence was not observed over 6 months. However, the tumors in other control groups treated only with SWCNTs or NIR irradiation continued to grow until the mice eventually died. In addition, most injected SWCNTs were excreted from the bodies of mice within 2 months via the biliary or urinary pathways. Huang et $\mathrm{al}^{132}$ studied the tumor destruction effect using a combination of $785 \mathrm{~nm}$ NIR laser and injected SWCNTs in tumor-bearing mice. After combination treatment, the temperature within the tumors was increased in an SWCNT and NIR irradiation dose-dependent manner. Squamous cell carcinomas were eradicated at a $200 \mathrm{~mW} / \mathrm{cm}^{2}$ light irradiance. Tissue Raman spectroscopy analysis results showed that SWCNTs remained localized in the tumors even at 3 months after injection. These results were a meaningful step for SWCNT-based photothermal cancer therapy for clinical applications.

Wang et $\mathrm{al}^{63}$ designed DTX-conjugated SWCNTs (DTXSWCNTs) linked to an NGR peptide to obtain a water-soluble and tumor-targeting DTX-NGR-SWCNT drug delivery system. SWCNTs-NGR-DTX showed higher targeting efficacy and inhibition than DTX and SWCNT-DTX in vitro in the PC-3 cell line and in vitro and in vivo murine S180 cancer model. In the in vivo model, tumor volumes in the DTXNGR-SWCNT group were significantly decreased under $808 \mathrm{~nm}$ NIR radiation compared to the control groups. They proposed the SWCNT-PEI/siRNA/NGR tumor targeting gene delivery system and combined the delivery system with NIR PTT. ${ }^{82}$ The combination of siRNA and PTT significantly increased the therapeutic efficacy in the in vitro PC-3 cell proliferation test and in vivo tumor-bearing mice model.

\section{A}
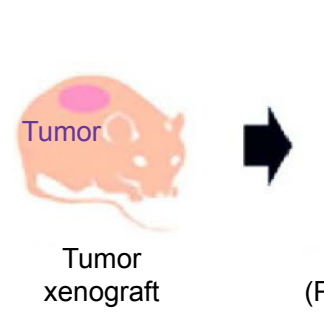

Intratumoral injection (PEG-SWCNTs or PBS)

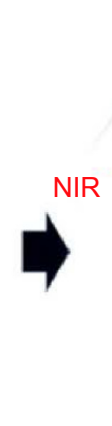

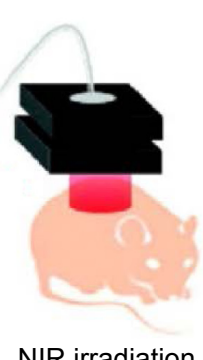

NIR irradiation

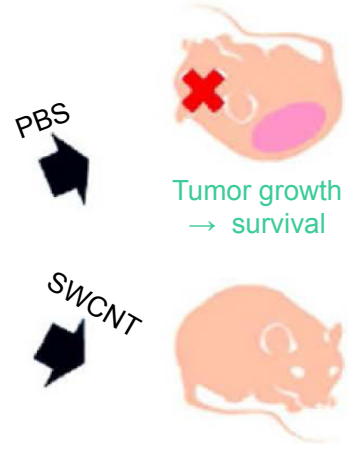

Tumor destruction $\rightarrow$ survival

\section{B}

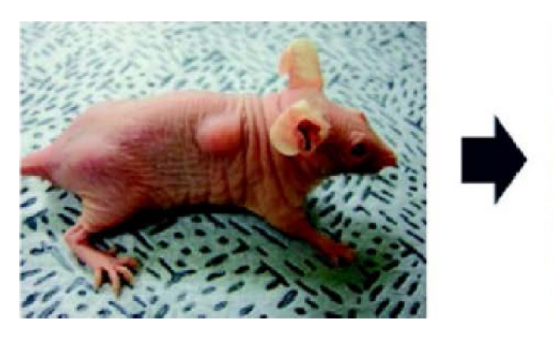

C

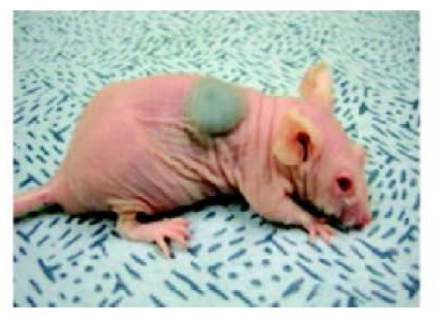

D

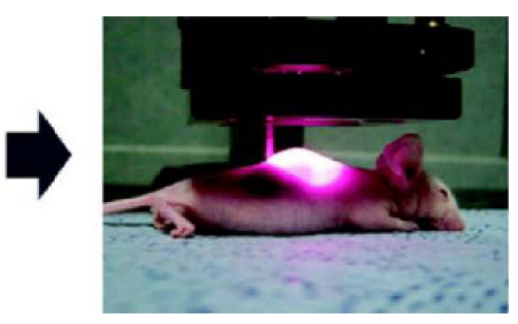

Figure 6 Photothermal treatments for in vivo tumor ablation using PEG-SWCNTs.

Notes: (A) Schematic view of the procedure and results of PEG-SWCNT-mediated photothermal treatment of tumors in mice; (B) photograph of a mouse bearing KB tumor cells $\left(\sim 70 \mathrm{~mm}^{3}\right)$; (C) photograph of a mouse after intratumoral injection of PEG-SWCNT solution $(\sim 120 \mathrm{mg} / \mathrm{L}, 100 \mu \mathrm{L})$; (D) photograph of NIR irradiation (808 $\mathrm{nm}$, $\left.76 \mathrm{~W} / \mathrm{cm}^{3}\right)$ for 3 minutes to tumor region. Reprinted with permission from Moon HK, Lee SH, Choi HC. In vivo near-infrared mediated tumor destruction by photothermal effect of carbon nanotubes. ACS Nano. 2009;3(II):3707-37I3. ${ }^{131}$ Copyright 2009 American Chemical Society.

Abbreviations: NIR, near infrared; PBS, phosphate-buffered saline; PEG, polyethylene glycol; SWCNTs, single-walled carbon nanotubes; KB, human epidermoid carcinoma. 
The high level of heat absorbance of CNTs from an NIR energy source has been exploited as a method for killing cancer cells through thermal effects. Numerous studies have demonstrated the effectiveness of PTT in in vitro experiments and in vivo animal models. In addition, effective laser energy levels, wavelengths, and treatment times were suggested. In addition, increased therapeutic efficacy resulting from the conjugation of CNTs with anticancer components has been reported. If the safety of CNTs can be confirmed in the body, PTT may be useful as an effective cancer therapy with minimal side effects.

\section{PDT for cancer treatment}

PDT is a noninvasive cancer therapy with minimal side effects. To utilize PDT, a light source, photosensitizer, and molecular oxygen are required. After the uptake of a photosensitizer into cancerous cells, the photosensitizer is activated by light at a specific wavelength and the excited photosensitizer transfers energy to oxygen molecules. Energy received by oxygen in a ground state is changed to excited singlet oxygen, which is cytotoxic. This cytotoxic oxygen irreversibly damages cancerous cells. ${ }^{135}$ Thus, CNTs show great potential as carriers of photosensitizers.

Ogbodu et al ${ }^{135}$ improved the PDT effect using a complex of SWCNTs and spermine-conjugated zinc mono carboxy phenoxy phthalocyanine (ZnMCPPc) in MCF-7 breast cancer cells. The ZnMCPPc-spermine-SWCNT complex increased the triplet and singlet oxygen quantum yields by $>50 \%$ compared to $\mathrm{ZnM}$ CPPc. When 5-40 $\mu \mathrm{M}$ of ZnMCPPc, ZnMCPPc-spermine, and ZnMCPPc-spermine-SWCNTs were incubated with MCF-7 cancer cells for 24 hours in the dark, all materials were found to be nontoxic. A PDT result at $40 \mu \mathrm{M} Z \mathrm{ZnMCPPc}$ showed an only $64 \%$ decrease in cell viability, but the PDT effect at $40 \mu \mathrm{M}$ ZnMCPPc-spermine improved to a $97 \%$ decrease in cell viability. For ZnMCPPc-spermine-SWCNTs, cell viability was decreased by $95 \%$, although the singlet oxygen quantum yield was lower compared to that of ZnMCPPc-spermine. Their results revealed that spermine-conjugated ZnMCPPc has potential as an agent for PDT.

Zhu et al ${ }^{136}$ developed single-stranded DNA aptamers attached to chlorin $6(\mathrm{Ce} 6)$ and wrapped their aptamers in SWCNTs to control the generation of singlet oxygen $\left({ }^{1} \mathrm{O}_{2}\right)$. When the aptamer target such as thrombin was absent, singlet oxygen generation (SOG) was prevented because the photosensitizing property of Ce6 was quenched by surrounding SWCNTs. When thrombin and aptamers were bound, the interaction between the aptamers and SWCNTs was weakened, leading to the restoration of the photodynamic activity of Ce6. Based on these experiments, introduction with $2.0 \mu \mathrm{M}$ thrombin resulted in a 13-fold enhancement of SOG. SOG was not efficiently triggered during incubation with other proteins such as BSA, protein A, protein L, NeutrAvidin, and immunoglobulin G. Notably, regulation of the activity of Ce6 may be useful for targeting specific tumor cells. Overall, these results indicated that PDT agents are useful for selective and controllable treatments.

Xiao et a ${ }^{137}$ developed Ce6-SWCNT complexes wrapped with CS to improve aqueous solubility and biocompatibility for PDT. High cellular uptake of CS-Ce6-SWCNTs was observed by flow cytometry and confocal microscopy, and the low dark toxicity and efficient PDT efficacy against HeLa cancer cells were confirmed in a water-soluble tetrazolium salt-1 (WST-1) assay. These results also demonstrated that CS-Ce6-SWCNTs are potential photosensitizer delivery systems for PDT.

Wang et al ${ }^{138}$ studied two f-SWCNTs to generate a photodynamic effect using visible light illumination in vitro and in vivo. Their results demonstrated that the photodynamic effect was dependent on the modification method of the SWCNTs and illumination and that PDT using SWCNT complexes significantly improved the therapeutic efficacy of cancer treatment. These findings also suggested that SWCNT complexes have potential as sensitizers for PDT.

Erbas et al ${ }^{139}$ proposed a pyrenyl-functionalized distyrylBodipy PDT sensitizer, which is attached to SWCNTs via non-covalent $\pi-\pi$ stacking. This sensitizer generated singlet oxygen when excited at $660 \mathrm{~nm}$ with a red light emitting diode array and showed slightly lower activity than the free compound. This work revealed the potential of SWCNTs as alternative carriers with a visibility of PDT sensitizers.

Huang et al ${ }^{140}$ studied polyamidoamine dendrimer-modified MWCNTs as carriers of the photosensitizer 5-aminolevulinic acid for tumor treatment. The incubation of human gastric cancer MGC-803 cells with the nanocomposites resulted in significant accumulation of protoporphyrin IX in the tumor cells and substantially increased the destruction of tumor cells after PDT treatment at $632 \mathrm{~nm}$. Their results suggested that these nanocarriers have remarkable photodynamic antitumor effects.

The photochemical property of CNTs that changes oxygen to singlet oxygen has been exploited as a method for killing cancer cells by cytotoxic oxygen. Earlier studies have suggested various photosensitizers, which were shown to be effective in in vitro cell studies and in vivo animal models. Although PDT-based cancer therapy is currently in an early stage of development, PDT has shown potential for selective and controllable treatments. 


\section{Combination of photothermal and photodynamic therapies for cancer \\ treatment}

Until now, PTT and PDT using CNTs have shown great potential for future cancer treatment. Hence, trials to improve the therapeutic efficacy by combining these two cancer treatment methods have been conducted in recent years and several promising results were presented.

Shi et al ${ }^{141}$ developed hematoporphyrin monomethyl ether (HMME)-adsorbed hyaluronic acid (HA)-conjugated CNTs (HMME-HA-CNTs). The tumor growth inhibition of HMME-HA-CNTs by a combination of PTT and PDT was investigated both in vivo and in vitro. The combination of PTT and PDT using the complex showed higher therapeutic efficacy for cancer treatment than PDT or PTT alone and did not have toxic effects in normal organs. In conclusion, their study demonstrated that HMME-HA-CNTs can be applied using a combination of PTT and PDT for future cancer therapy.

Zhang et $a^{142}$ developed ruthenium (Ru)(II) complexfunctionalized SWCNTs for PTT and two-photon PDT (PTT-TPPDT). SWCNTs can load large amounts of Ru(II) complexes via $\pi-\pi$ interactions, and the loaded complexes showed photothermal effects following treatment with an NIR laser (808 $\mathrm{nm}$ wavelength). In addition, the released complexes produced singlet oxygen species $\left({ }^{1} \mathrm{O}_{2}\right)$ for PDT upon two-photon laser irradiation $\left(808 \mathrm{~nm}, 0.25 \mathrm{~W} / \mathrm{cm}^{2}\right)$. In vitro and in vivo tumor ablation studies showed excellent treatment efficacy using their PTT-TPPDT method. These results revealed a potential of the bimodal platform of PTT and TPPDT for cancer therapy (Figure 7).

Marangon et a $1^{143}$ utilized MWCNTs and the photosensitizer m-tetrahydroxyphenylchlorin (mTHPC) for cancer therapy using a combination of PTT and PDT. A cytotoxicity test using SKOV3 ovarian cancer cells showed that cytotoxicity at the cellular level was correlated with the uptake of mTHPC/MWCNTs. They also found that PDT and PTT treatment induced different signaling pathways, leading to cell apoptosis. In addition, the mechanisms of PDT/PTT synergy in cancer annihilation were evaluated using flow cytometry and proteomic and genomic analyses. Their results provided insight into the molecular and cellular responses to light therapy using photoactive nanomaterial.

\section{Conclusion and future perspectives}

CNTs have received great attention in biomedical fields because of their unique structures and properties, including high aspect ratios, large surface areas, rich surface chemical functionalities, and size stability on the nanoscale. Particularly, CNTs are attractive transporters for drug delivery and mediators of noninvasive therapy. Appropriate functionalization enables the use of CNTs as nanocarriers to transport anticancer drugs such as DOX, CPT, CP, CDDP, PTX, and DTX. CNTs have also been used as carriers for genes such as pDNA, siRNA, ODNs, and RNA/DNA aptamers. CTNs
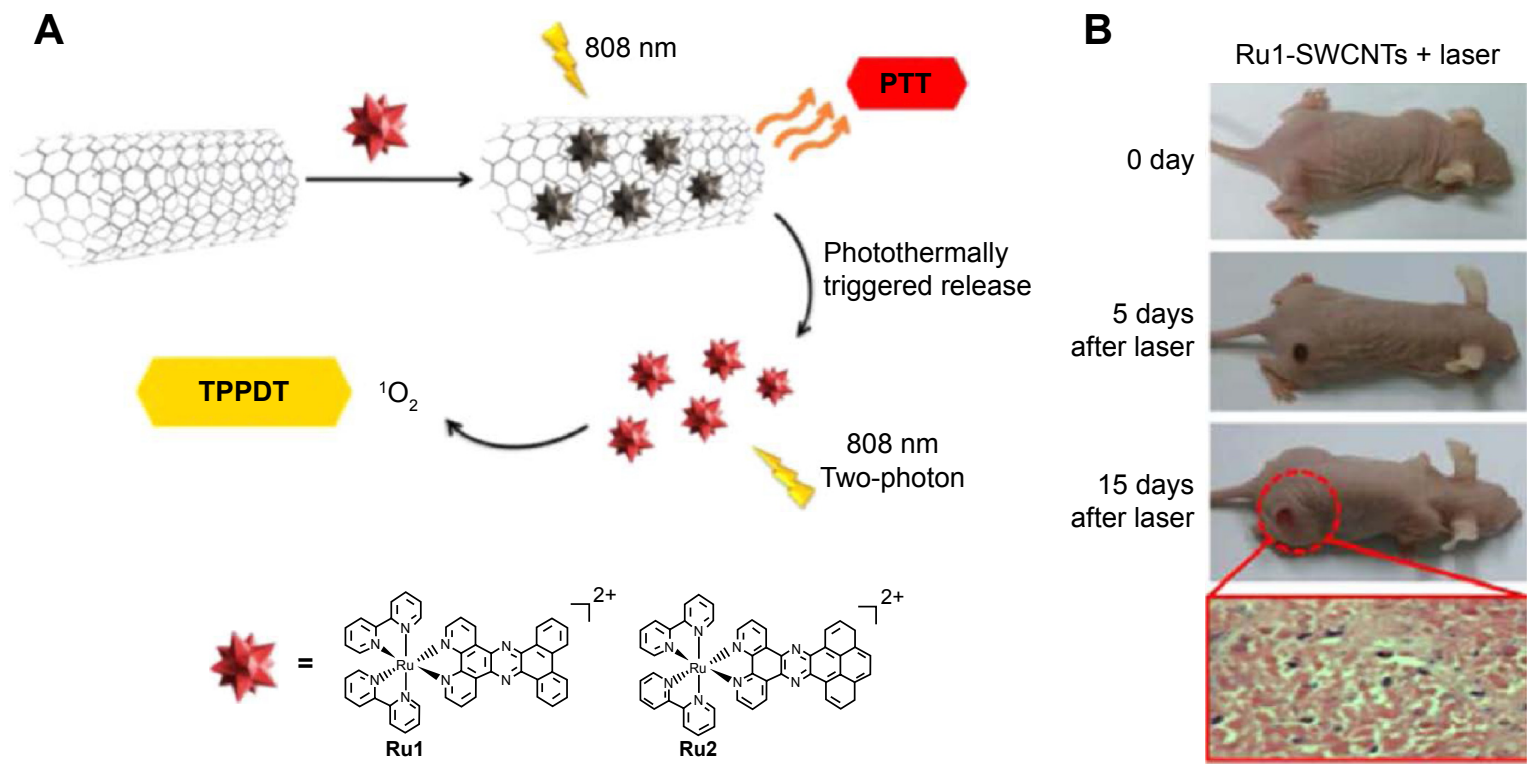

Figure 7 Bimodal therapy of PTT and TPPDT using Ru-SWCNTs.

Notes: (A) Schematic design of Ru-SWCNTs for bimodal PTT and TPPDT with $808 \mathrm{~nm}$ irradiation. (B) Representative photographs of HeLa tumors in mice. Reprinted with permission from Zhang P, Huang H, Huang J, et al. Noncovalent ruthenium(II) complexes-single-walled carbon nanotube composites for bimodal photothermal and photodynamic therapy with near-infrared irradiation. ACS Appl Mater Interfaces. 20I5;7(4I):23278-23290. ${ }^{142}$ Copyright 2015 American Chemical Society.

Abbreviations: PTT, photothermal therapy; SWCNTs, single-walled carbon nanotubes; TPPDT, two-photon photodynamic therapy. 
can also deliver proteins and immunotherapy components. A combination of light energy such as NIR and CNTs enables their use in noninvasive therapeutic techniques. CNTs have been used as mediators for PTT and PDT to directly destroy cancer cells without severely damaging normal tissue.

Although many studies have shown promising results for CNT-based therapies in vitro and in vivo, there are several limitations to the clinical applications of these methods. First, safety issues in the human body have not been adequately addressed. Although many in vitro tests showed the safety of f-CNTs, most in vivo toxicity tests were conducted over a relatively short time. Long-term safety has gained increasing attention, and in vivo studies related to long-term toxicity and external excretion of CNTs have shown some progress. In addition, efforts have been made to minimize toxicity via the purification and surface functionalization of CNTs. Second, the size uniformity of synthesized CNTs and uniformity of the loading amount at drug-CNT complexes must be improved. To increase the uniformity of CNTs, many strategies including control of the synthetic catalyst, growth temperature, environmental gas pressure, flux, and composition of the feedstock gas have been proposed and studied over the past several decades. To increase loading uniformity, various functionalization methods using covalent or non-covalent surface binding of molecules have been engrafted to CNT-based drug loading systems. In addition, the accuracy of targeting cancer cells and controllability of loaded drugs should be improved. As described earlier, various CNT functionalization strategies using various molecules and materials have been reported to enhance the activity and stability of drug-CNTs. Additional studies will improve these methods for clinical application, and CNTs will become one of the strongest tools in various other biomedical fields as well as cancer therapy.

\section{Acknowledgments}

This research was supported by the National Research Foundation of Korea (NRF) grant (No 2014R1A1A2A16054777) and Korea Health Industry Development Institute (KHIDI) grant (HI13C-1602-010015) funded by the Korea government and Gachon University Gil Medical Center (No FRD2014-02-02).

\section{Disclosure}

The authors report no conflicts of interest in this work.

\section{References}

1. Bandyopadhyay A, Das T, Yeasmin S. Nanoparticles in Lung Cancer Therapy: Recent Trends. Berlin, Germany: Springer International Publishing; 2015:1-15.
2. Luo J, Solimini NL, Elledge SJ. Principles of cancer therapy: oncogene and nononcogene addiction. Cell. 2009;136(5):823-837.

3. Hanahan D, Weinberg RA. The hallmarks of cancer. Cell. 2000;100(1): $57-70$.

4. World Health Organization, Cancer; 2015, Fact Sheet \#297. Available from: http://www.who.int/mediacentre/factsheets/fs297/en/. Accessed August 17, 2016.

5. Iijima S. Helical microtubules of graphitic carbon. Nature. 1991;354: $56-58$.

6. Elhissi AM, Ahmed W, Hassan IU, Dhanak VR, D'Emanuele A. Carbon nanotubes in cancer therapy and drug delivery. J Drug Deliv. 2012;2012:837327.

7. Wong BS, Yoong SL, Jagusiak A, et al. Carbon nanotubes for delivery of small molecule drugs. Adv Drug Deliv Rev. 2013;65(15):1964-2015.

8. Tian Z, Yin M, Ma H, Zhu L, Shen H, Jia N. Supramolecular assembly and antitumor activity of multiwalled carbon nanotube-camptothecin complexes. J Nanosci Nanotechnol. 2011;11(2):953-958.

9. Wu W, Li R, Bian X, et al. Covalently combining carbon nanotubes with anticancer agent: preparation and antitumor activity. ACS Nano. 2009;3(9):2740-2750.

10. Tripisciano C, Rummeli MH, Chen XC, Borowiak-Palen E. Multiwall carbon nanotubes-a vehicle for targeted irinotecan drug delivery. Physica Status Solidi B. 2010;247:2673-2677.

11. Chen C, Xie XX, Zhou Q, et al. EGF-functionalized single-walled carbon nanotubes for targeting delivery of etoposide. Nanotechnology. 2012;23(4):045104.

12. Huang H, Yuan Q, Shah JS, Misra RD. A new family of folate-decorated and carbon nanotube-mediated drug delivery system: synthesis and drug delivery response. Adv Drug Deliv Rev. 2011;63:1332-1339.

13. Zhang X, Meng L, Lu Q, Fei Z, Dyson PJ. Targeted delivery and controlled release of doxorubicin to cancer cells using modified single wall carbon nanotubes. Biomaterials. 2009;30(30):6041-6047.

14. Heister E, Neves V, Lamprecht C, Silva SRP, Coley HM, McFadden J. Drug loading, dispersion stability, and therapeutic efficacy in targeted drug delivery with carbon nanotubes. Carbon N Y. 2012;50: 622-632.

15. Wen S, Liu H, Cai H, Shen M, Shi X. Targeted and pH-responsive delivery of doxorubicin to cancer cells using multifunctional dendrimermodified multi-walled carbon nanotubes. Adv Healthc Mater. 2013; 2(9):1267-1276.

16. Niu L, Meng L, Lu Q. Folate-conjugated PEG on single walled carbon nanotubes for targeting delivery of doxorubicin to cancer cells. Macromol Biosci. 2013;13(6):735-744.

17. Di Crescenzo A, Velluto D, Hubbell JA, Fontana A. Biocompatible dispersions of carbon nanotubes: a potential tool for intracellular transport of anticancer drugs. Nanoscale. 2011;3(3):925-928.

18. Mashat A, Deng L, Altawashi A, Sougrat R, Wang GC, Khashab NM. Zippered release from polymer-gated carbon nanotubes. J Mater Chem. 2012;22:11503-11508.

19. Zhao Q, Zhang JM, Wang R, Cong RW. Use of a thermocouple for malignant tumor detection. Investigating temperature difference as a diagnostic criterion. IEEE Eng Med Biol Mag. 2008;27:64-66.

20. Liu Z, Sun X, Nakayama-Ratchford N, Dai H. Supramolecular chemistry on water-soluble carbon nanotubes for drug loading and delivery. ACS Nano. 2007;1(1):50-56.

21. Ali-Boucetta H, Al-Jamal KT, McCarthy D, Prato M, Bianco A, Kostarelos K. Multiwalled carbon nanotube-doxorubicin supramolecular complexes for cancer therapeutics. Chem Commun. 2008;4:459-461.

22. Li R, Wu R, Zhao L. Folate and iron difunctionalized multiwall carbon nanotubes as dual-targeted drug nano-carrier to cancer cells. Carbon $N Y$. 2011;49(5):1797-1805.

23. Ji Z, Lin G, Lu Q, et al. Targeted therapy of SMMC-7721 liver cancer in vitro and in vivo with carbon nanotubes based drug delivery system. J Colloid Interface Sci. 2012;365(1):143-149.

24. Lu YJ, Wei KC, Ma CCM, Yang SY, Chen JP. Dual targeted delivery of doxorubicin to cancer cells using folate-conjugated magnetic multiwalled carbon nanotubes. Colloids Surf B Biointerfaces. 2012;89:1-9. 
25. Datir SR, Das M, Singh RP, Jain S. Hyaluronate tethered, "smart" multiwalled carbon nanotubes for tumor-targeted delivery of doxorubicin. Bioconjug Chem. 2012;23(11):2201-2213.

26. Das M, Singh RP, Datir SR, Jain S. Surface chemistry dependent "switch" regulates the trafficking and therapeutic performance of drugloaded carbon nanotubes. Bioconjug Chem. 2013;24(4):626-639.

27. Lodhi N, Mehra NK, Jain NK. Development and characterization of dexamethasone mesylate anchored on multi walled carbon nanotubes. J Drug Target. 2013;21(1):67-76.

28. Heister E, Neves V, Tilmaciu C, et al. Triple functionalization of singlewalled carbon nanotubes with doxorubicin, a monoclonal antibody, and a fluorescent marker for targeted cancer therapy. Carbon $N Y$. 2009;47:2152-2160.

29. Li R, Wu R, Zhao L, Wu M, Yang L, Zou H. P-glycoprotein antibody functionalized carbon nanotube overcomes the multidrug resistance of human leukemia cells. ACS Nano. 2010;4(3):1399-1408.

30. Wu H, Liu G, Wang X, et al. Solvothermal synthesis of cobalt ferrite nanoparticles loaded on multiwalled carbon nanotubes for magnetic resonance imaging and drug delivery. Acta Biomater. 2011; 7(9):3496-3504.

31. Peci T, John T, Dennis S, Baxendale M. Iron-filled multiwalled carbon nanotubes surface-functionalized with paramagnetic Gd (III): A candidate dual-functioning MRI contrast agent and magnetic hyperthermia structure. Carbon N Y. 2015;87:226-232.

32. Chen Z, Pierre D, He H, et al. Adsorption behavior of epirubicin hydrochloride on carboxylated carbon nanotubes. Int J Pharm. 2011; 405(1-2):153-161.

33. Taghdisi SM, Lavaee P, Ramezani M, Abnous K. Reversible targeting and controlled release delivery of daunorubicin to cancer cells by aptamer-wrapped carbon nanotubes. Eur J Pharm Biopharm. 2011; 77(2):200-206.

34. Wheate NJ, Walker S, Craig GE, Oun R. The status of platinum anticancer drugs in the clinic and in clinical trials. Dalton Trans. 2010;39(35):8113-8127.

35. Lilley DMJ. Cisplatin adducts in DNA: distortion and recognition J Biol Inorg Chem. 1996;1:189-191.

36. Wang D, Lippard SJ. Cellular processing of platinum anticancer drugs. Nat Rev Drug Discov. 2005;4(4):307-320.

37. Chin CF, Tian Q, Setyawati MI, et al. Tuning the activity of platinum(IV) anticancer complexes through asymmetric acylation. J Med Chem. 2012;55(17):7571-7582.

38. Chin CF, Wong DY, Jothibasu R, Ang WH. Anticancer platinum (IV) prodrugs with novel modes of activity. Curr Top Med Chem. 2011;11(21): 2602-2612.

39. Galanski M, Jakupec MA, Keppler BK. Update of the preclinical situation of anticancer platinum complexes: novel design strategies and innovative analytical approaches. Curr Med Chem. 2005;12(18): 2075-2094.

40. Xu P, Van Kirk EA, Murdoch WJ, et al. Anticancer efficacies of cisplatin-releasing $\mathrm{pH}$-responsive nanoparticles. Biomacromolecules. 2006;7(3):829-835.

41. Dhar S, Liu Z, Thomale J, Dai HJ, Lippard SJ. Targeted single-wall carbon nanotube-mediated Pt(IV) prodrug delivery using folate as a homing device. J Am Chem Soc. 2008;130(34):11467-11476.

42. Tripisciano C, Kraemer K, Taylor A, Borowiak-Palen E. Single-wall carbon nanotubes based anticancer drug delivery system. Chem Phys Lett. 2009;478:200-205.

43. Feazell RP, Nakayama-Ratchford N, Dai H, Lippard SJ. Soluble single-walled carbon nanotubes as longboat delivery systems for platinum(IV) anticancer drug design. J Am Chem Soc. 2007;129(27): 8438-8439.

44. Bhirde AA, Patel V, Gavard J, et al. Targeted killing of cancer cells in vivo and in vitro with EGF-directed carbon nanotube-based drug delivery. ACS Nano. 2009;3(2):307-316.

45. Bhirde AA, Sousa AA, Patel V, et al. Imaging the distribution of individual platinum-based anticancer drug molecules attached to single-wall carbon nanotubes. Nanomedicine (Lond). 2009;4(7):763-772.
46. Guven A, Rusakova IA, Lewis MT, Wilson LJ. Cisplatin@US-tube carbon nanocapsules for enhanced chemotherapeutic delivery. Biomaterials. 2012;33(5):1455-1461.

47. Kolosnjaj-Tabi J, Hartman KB, Boudjemaa S, et al. In vivo behavior of large doses of ultrashort and full-length single-walled carbon nanotubes after oral and intraperitoneal administration to Swiss mice. ACS Nano. 2010;4(3):1481-1492.

48. Yang F, Fu de L, Long J, Ni QX. Magnetic lymphatic targeting drug delivery system using carbon nanotubes. Med Hypotheses. 2008;70(4): 765-767.

49. Yang F, Hu J, Yang D, et al. Pilot study of targeting magnetic carbon nanotubes to lymph nodes. Nanomedicine (Lond). 2009;4(3):317-330.

50. Hampel S, Kunze D, Haase D, et al. Carbon nanotubes filled with a chemotherapeutic agent: a nano-carrier mediates inhibition of tumor cell growth. Nanomedicine (Lond). 2008;3(2):175-182.

51. Arlt M, Haase D, Hampel S, et al. Delivery of carboplatin by carbonbased nanocontainers mediates increased cancer cell death. Nanotechnology. 2010;21(33):335101.

52. Foley EA, Kapoor TM. Microtubule attachment and spindle assembly checkpoint signalling at the kinetochore. Nat Rev Mol Cell Biol. 2013; 14(1):25-37.

53. Arya N, Arora A, Vasu KS, Sood AK, Katti DS. Combination of single walled carbon nanotubes/graphene oxide with paclitaxel: a reactive oxygen species mediated synergism for treatment of lung cancer. Nanoscale. 2013;5(7):2818-2829.

54. Zhang W, Zhang D, Tan J, Cong H. Carbon nanotube exposure sensitize human ovarian cancer cells to paclitaxel. J Nanosci Nanotechnol. 2012;12(9):7211-7214.

55. Chen J, Chen S, Zhao X, Kuznetsova LV, Wong SS, Ojima I. Functionalized single-walled carbon nanotubes as rationally designed vehicles for tumortargeted drug delivery. J Am Chem Soc. 2008;130(49):16778-16785.

56. Sobhani Z, Dinarvand R, Atyabi F, Ghahremani M, Adeli M. Increased paclitaxel cytotoxicity against cancer cell lines using a novel functionalized carbon nanotube. Int J Nanomedicine. 2011;6:705-719.

57. Li C, Yu D, Inoue T, et al. Synthesis and evaluation of water-soluble polyethylene glycol-paclitaxel conjugate as a paclitaxel prodrug. Anticancer Drug. 1996;7(6):642-648.

58. Liu Z, Chen K, Davis C, et al. Drug delivery with carbon nanotubes for in vivo cancer treatment. Cancer Res. 2008;68(16):6652-6660.

59. Lay CL, Liu HQ, Tan HR, Liu Y. Delivery of paclitaxel by physically loading onto poly(ethylene glycol) (PEG)-graft-carbon nanotubes for potent cancer therapeutics. Nanotechnology. 2010;21(6):065101.

60. Lee Y, Geckeler KE. Cellular interactions of a water-soluble supramolecular polymer complex of carbon nanotubes with human epithelial colorectal adenocarcinoma cells. Macromol Biosci. 2012;12(8): 1060-1067.

61. Moore TL, Pitzer JE, Podila R, et al. Multifunctional polymer-coated carbon nanotubes for safe drug delivery. Part Part Syst Char. 2013;30: $365-373$.

62. Wu CH, Cao C, Kim JH, et al. Trojan-horse nanotube on-command intracellular drug delivery. Nano Lett. 2012;12(11):5475-5480.

63. Wang L, Zhang M, Zhang N, et al. Synergistic enhancement of cancer therapy using a combination of docetaxel and photothermal ablation induced by single-walled carbon nanotubes. Int J Nanomedicine. 2011;6: 2641-2652.

64. Pantarotto D, Singh R, McCarthy D, et al. Functionalized carbon nanotubes for plasmid DNA gene delivery. Angew Chem Int Edit. 2004; 43(39):5242-5246.

65. Gao L, Nie L, Wang T, et al. Carbon nanotube delivery of the GFP gene into mammalian cells. Chembiochem. 2006;7(2):239-242.

66. Singh R, Pantarotto D, McCarthy D, et al. Binding and condensation of plasmid DNA onto functionalized carbon nanotubes: toward the construction of nanotube-based gene delivery vectors. J Am Chem Soc. 2005; 127(12):4388-4396.

67. Liu X, Zhang Y, Ma D, et al. Biocompatible multi-walled carbon nanotube-chitosan-folic acid nanoparticle hybrids as GFP gene delivery materials. Colloid Surface B. 2013;111:224-231. 
68. Behnam B, Shier WT, Nia AH, Abnous K, Ramezani M. Noncovalent functionalization of single-walled carbon nanotubes with modified polyethyleneimines for efficient gene delivery. Int J Pharm. 2013;454(1):204-215.

69. Inoue Y, Fujimoto H, Ogino T, Iwata H. Site-specific gene transfer with high efficiency onto a carbon nanotube-loaded electrode. $J R$ Soc Interface. 2008;5(25):909-918.

70. Qin W, Yang K, Tang H, et al. Improved GFP gene transfection mediated by polyamidoamine dendrimer-functionalized multi-walled carbon nanotubes with high biocompatibility. Colloid Surface B Biointerfaces. 2011;84(1):206-213.

71. Ahmed M, Jiang X, Deng Z, Narain R. Cationic glyco-functionalized single-walled carbon nanotubes as efficient gene delivery vehicles. Bioconjug Chem. 2009;20(11):2017-2022.

72. Karmakar A, Bratton SM, Dervishi E, et al. Ethylenediamine functionalized-single-walled nanotube (f-SWNT)-assisted in vitro delivery of the oncogene suppressor p53 gene to breast cancer MCF-7 cells. Int J Nanomedicine. 2011;6:1045-1055.

73. Cai D, Mataraza JM, Qin ZH, et al. Highly efficient molecular delivery into mammalian cells using carbon nanotube spearing. Nat Methods. 2005;2(6):449-454.

74. Hao Y, Xu P, He C, et al. Impact of carbondiimide crosslinker used for magnetic carbon nanotube mediated GFP plasmid delivery. Nanotechnology. 2011;22(28):285103.

75. Paul A, Shao W, Shum-Tim D, Prakash S. The attenuation of restenosis following arterial gene transfer using carbon nanotube coated stent incorporating TAT/DNA (Ang1+Vegf) nanoparticles. Biomaterials. 2012;33(30):7655-7664.

76. Wang X, Ren J, Qu X. Targeted RNA interference of cyclin A2 mediated by functionalized single-walled carbon nanotubes induces proliferation arrest and apoptosis in chronic myelogenous leukemia K562 cells. ChemMedChem. 2008;3(6):940-945.

77. Varkouhi AK, Foillard S, Lammers T, et al. SiRNA delivery with functionalized carbon nanotubes. Int J Pharm. 2011;416(2):419-425.

78. Podesta JE, Al-Jamal KT, Herrero MA, et al. Antitumor activity and prolonged survival by carbon-nanotube-mediated therapeutic siRNA silencing in a human lung xenograft model. Small. 2009;5(10):1176-1185.

79. Zhang Z, Yang X, Zhang Y, et al. Delivery of telomerase reverse transcriptase small interfering RNA in complex with positively charged single-walled carbon nanotubes suppresses tumor growth. Clin Cancer Res. 2006;12(16):4933-4939.

80. Al-Jamal KT, Gherardini L, Bardi G, et al. Functional motor recovery from brain ischemic insult by carbon nanotube-mediated siRNA silencing. Proc Natl Acad Sci US A. 2011;108(27):10952-10957.

81. Ladeira MS, Andrade VA, Gomes ER, et al. Highly efficient siRNA delivery system into human and murine cells using single-wall carbon nanotubes. Nanotechnology. 2010;21(38):385101.

82. Wang L, Shi J, Zhang H, et al. Synergistic anticancer effect of RNAi and photothermal therapy mediated by functionalized single-walled carbon nanotubes. Biomaterials. 2013;34(1):262-274.

83. Krajcik R, Jung A, Hirsch A, Neuhuber W, Zolk O. Functionalization of carbon nanotubes enables non-covalent binding and intracellular delivery of small interfering RNA for efficient knock-down of genes. Biochem Bioph Res Commun. 2008;369(2):595-602.

84. Kam NW, Liu Z, Dai H. Functionalization of carbon nanotubes via cleavable disulfide bonds for efficient intracellular delivery of siRNA and potent gene silencing. J Am Chem Soc. 2005;127(36):12492-12493.

85. Liu Z, Winters M, Holodniy M, Dai H. siRNA delivery into human $\mathrm{T}$ cells and primary cells with carbon-nanotube transporters. Angew Chem Int Edit. 2007;46(12):2023-2027.

86. McCarroll J, Baigude H, Yang CS, Rana TM. Nanotubes functionalized with lipids and natural amino acid dendrimers: a new strategy to create nanomaterials for delivering systemic RNAi. Bioconjug Chem. 2010;21(1):56-63.

87. Chen H, Ma X, Li Z, et al. Functionalization of single-walled carbon nanotubes enables efficient intracellular delivery of siRNA targeting MDM2 to inhibit breast cancer cells growth. Biomed Pharmacother. 2012;66(5):334-338.
88. Neves V, Heister E, Costa S, et al. Design of double-walled carbon nanotubes for biomedical applications. Nanotechnology. 2012;23(36): 365102.

89. Bartholomeusz G, Cherukuri P, Kingston J, et al. In vivo therapeutic silencing of hypoxia-inducible factor 1 alpha (HIF-1 $\alpha$ ) using singlewalled carbon nanotubes noncovalently coated with siRNA. Nano Res. 2009;2(4):279-291.

90. Lanner JT, Bruton JD, Assefaw-Redda Y, et al. Knockdown of TRPC-3 with siRNA coupled to carbon nanotubes results in decreased insulinmediated glucose uptake in adult skeletal muscle cells. FASEB J. 2009;23(6):1728-1738.

91. Al-Jamal KT, Toma FM, Yilmazer A, et al. Enhanced cellular internalization and gene silencing with a series of cationic dendronmultiwalled carbon nanotube:siRNA complexes. FASEB J. 2010;24(11):4354-4365.

92. Crinelli R, Carloni E, Menotta M, et al. Oxidized ultrashort nanotubes as carbon scaffolds for the construction of cell-penetrating NF-kappaB decoy molecules. ACS Nano. 2010;4(5):2791-2803.

93. Jia N, Lian Q, Shen H, Wang C, Li X, Yang Z. Intracellular delivery of quantum dots tagged antisense oligodeoxynucleotides by functionalized multiwalled carbon nanotubes. Nano Lett. 2007;7(10):2976-2980.

94. Pan B, Cui D, Xu P, et al. Synthesis and characterization of polyamidoamine dendrimer-coated multi-walled carbon nanotubes and their application in gene delivery systems. Nanotechnology. 2009; 20(12):125101.

95. Van den Bossche J, Al-Jamal WT, Tian B, et al. Efficient receptorindependent intracellular translocation of aptamers mediated by conjugation to carbon nanotubes. Chem Commun. 2010;46(39):7379-7381.

96. Bates K, Kostarelos K. Carbon nanotubes as vectors for gene therapy: past achievements, present challenges and future goals. Adv Drug Deliv Rev. 2013;65:2023-2033.

97. Fortunati E, Bout A, Zanta MA, Valerio D, Scarpa M. In vitro and in vivo gene transfer to pulmonary cells mediated by cationic liposomes. Biochim Biophys Acta. 1996;1306(1):55-62.

98. Ledley FD. Non-viral gene therapy. Curr Opin Biotech. 1994;5(6): 626-636.

99. Mohammadi M, Salmasi Z, Hashemi M, Mosaffa F, Abnous K, Ramezani M. Single-walled carbon nanotubes functionalized with aptamer and piperazine-polyethylenimine derivative for targeted siRNA delivery into breast cancer cells. Int J Pharm. 2015;485:50-60.

100. Hussey SL, Peterson BR. Efficient delivery of streptavidin to mammalian cells: clathrin-mediated endocytosis regulated by a synthetic ligand. J Am Chem Soc. 2002;124(22):6265-6273.

101. Shi Kam NW, Jessop TC, Wender PA, Dai H. Nanotube molecular transporters: internalization of carbon nanotube-protein conjugates into Mammalian cells. J Am Chem Soc. 2004;126(22):6850-6851.

102. Parra J, Abad-Somovilla A, Mercader JV, Taton TA, Abad-Fuentes A. Carbon nanotube-protein carriers enhance size-dependent self-adjuvant antibody response to haptens. J Control Release. 2013;170(2): 242-251.

103. Weng X, Wang M, Ge J, et al. Carbon nanotubes as a protein toxin transporter for selective HER2-positive breast cancer cell destruction. Mol Biosyst. 2009;5(10):1224-1231.

104. Li C, Yang K, Zhang Y, et al. Highly biocompatible multi-walled carbon nanotube-chitosan nanoparticle hybrids as protein carriers. Acta Biomater. 2011;7(8):3070-3077.

105. Sanz V, Coley HM, Silva SRP, McFadden J. Modeling the binding of peptides on carbon nanotubes and their use as protein and DNA carriers. J Nanopart Res. 2012;14:695.

106. McDevitt MR, Chattopadhyay D, Kappel BJ, et al. Tumor targeting with antibody-functionalized, radiolabeled carbon nanotubes. $J \mathrm{Nucl}$ Med. 2007;48(7):1180-1189.

107. Ruggiero A, Villa CH, Holland JP, et al. Imaging and treating tumor vasculature with targeted radiolabeled carbon nanotubes. Int $J$ Nanomedicine. 2010;5:783-802.

108. Meng J, Yang M, Jia F, et al. Subcutaneous injection of water-soluble multi-walled carbon nanotubes in tumor-bearing mice boosts the host immune activity. Nanotechnology. 2010;21(14):145104. 
109. Yang L, Ng KY, Lillehei KO. Cell-mediated immunotherapy: a new approach to the treatment of malignant glioma. Cancer Control. 2003;10(2):138-147.

110. Parney IF, Hao C, Petruk KC. Glioma immunology and immunotherapy. Neurosurgery. 2000;46(4):778-791.

111. Van Handel M, Alizadeh D, Zhang L, et al. Selective uptake of multiwalled carbon nanotubes by tumor macrophages in a murine glioma model. J Neuroimmunol. 2009;208(1-2):3-9.

112. Fadel TR, Sharp FA, Vudattu N, et al. A carbon nanotube-polymer composite for T-cell therapy. Nat Nanotechnol. 2014;9(8):639-647.

113. Fan $\mathrm{H}$, Zhang I, Chen $\mathrm{X}$, et al. Intracerebral $\mathrm{CpG}$ immunotherapy with carbon nanotubes abrogates growth of subcutaneous melanomas in mice. Clin Cancer Res. 2012;18(20):5628-5638.

114. Zhao D, Alizadeh D, Zhang L, et al. Carbon nanotubes enhance CpG uptake and potentiate antiglioma immunity. Clin Cancer Res. 2011;17(4): 771-782.

115. Ouyang M, White EE, Ren H, et al. Metronomic doses of temozolomide enhance the efficacy of carbon nanotube $\mathrm{CpG}$ immunotherapy in an invasive glioma model. PLoS One. 2016;11(2):e0148139.

116. Villa CH, Dao T, Aheam I, et al. Single-walled carbon nanotubes deliver peptide antigen into dendritic cells and enhance $\mathrm{IgG}$ responses to tumor-associated antigens. ACS Nano. 2011;5(7):5300-5311.

117. Sacchetti C, Rapini N, Magrini A, et al. In vivo targeting of intratumor regulatory $\mathrm{T}$ cells using PEG-modified single-walled carbon nanotubes. Bioconjug Chem. 2013;24(6):852-858.

118. Meng J, Meng J, Duan J, et al. Carbon nanotubes conjugated to tumor lysate protein enhance the efficacy of an antitumor immunotherapy. Small. 2008;4(9):1364-1370

119. Li Q, Ruan H, Li H. Nanocarbon materials for photodynamic therapy and photothermal therapy. Pharmaceutical Nanotechnol. 2014;2(2): 58-64.

120. Brennan ME, Coleman JN, Drury A, Lahr B, Kobayashi T, Blau WJ. Nonlinear photoluminescence from van Hove singularities in multiwalled carbon nanotubes. Opt Lett. 2003;28(4):266-268.

121. Gannon CJ, Cherukuri P, Yakobson BI, et al. Carbon nanotubeenhanced thermal destruction of cancer cells in a noninvasive radiofrequency field. Cancer. 2007;110(12):2654-2665.

122. Torti SV, Byrne F, Whelan O, et al. Thermal ablation therapeutics based on CNx multi-walled nanotubes. Int J Nanomed. 2007;2:707-714.

123. Zhou F, Xing D, Ou Z, Wu B, Resasco DE, Chen WR. Cancer photothermal therapy in the near-infrared region by using single-walled carbon nanotubes. J Biomed Opt. 2009;14(2):021009.

124. Zhou F, Wu S, Wu B, Chen WR, Xing D. Mitochondria-targeting single-walled carbon nanotubes for cancer photothermal therapy. Small. 2011;7(19):2727-2735

125. Zhou F, Wu S, Song S, Chen WR, Resasco DE, Xing D. Antitumor immunologically modified carbon nanotubes for photothermal therapy. Biomaterials. 2012;33(11):3235-3242.

126. Wang $\mathrm{CH}$, Huang YJ, Chang $\mathrm{CW}$, Hsu WM, Peng CA. In vitro photothermal destruction of neuroblastoma cells using carbon nanotubes conjugated with GD2 monoclonal antibody. Nanotechnology. 2009;20(31):315101.

127. Burke A, Ding X, Singh R, et al. Long-term survival following a single treatment of kidney tumors with multiwalled carbon nanotubes and near-infrared radiation. Proc Natl Acad Sci U S A. 2009; 106(31):12897-12902.
128. Burlaka A, Lukin S, Prylutska S, et al. Hyperthermic effect of multiwalled carbon nanotubes stimulated with near infrared irradiation for anticancer therapy: in vitro studies. Exp Oncol. 2010;32(1):48-50.

129. Ghosh S, Dutta S, Gomes E, et al. Increased heating efficiency and selective thermal ablation of malignant tissue with DNA-encased multiwalled carbon nanotubes. ACS Nano. 2009;3(9):2667-2673.

130. Xiao Y, Gao X, Taratula O, et al. Anti-HER2 IgY antibody functionalized single-walled carbon nanotubes for detection and selective destruction of breast cancer cells. BMC Cancer. 2009;9(1471):351.

131. Moon HK, Lee SH, Choi HC. In vivo near-infrared mediated tumor destruction by photothermal effect of carbon nanotubes. ACS Nano. 2009;3(11):3707-3713.

132. Huang N, Wang H, Zhao J, Lui H, Korbelik M, Zeng H. Single-wall carbon nanotubes assisted photothermal cancer therapy: animal study with a murine model of squamous cell carcinoma. Lasers Surg Med. 2010;42(9):638-648.

133. Liu X, Tao H, Yang K, Zhang S, Lee ST, Liu Z. Optimization of surface chemistry on single-walled carbon nanotubes for in vivo photothermal ablation of tumors. Biomaterials. 2011;32(1):144-151.

134. Kam NW, O'Connell M, Wisdom JA, Dai H. Carbon nanotubes as multifunctional biological transporters and near-infrared agents for selective cancer cell destruction. Proc Natl Acad Sci U S A. 2005; 102(33):11600-11605.

135. Ogbodu RO, Limson JL, Prinsloo E, Nyokong T. Photophysical properties and photodynamic therapy effect of zinc phthalocyaninespermine-single walled carbon nanotube conjugate on MCF-7 breast cancer cell line. Synthetic Met. 2015;204:122-132.

136. Zhu Z, Tang Z, Phillips JA, Yang R, Wang H, Tan W. Regulation of singlet oxygen generation using single-walled carbon nanotubes. J Am Chem Soc. 2008;130(33):10856-10857.

137. Xiao HR, Zhu BS, Wang DL, et al. Photodynamic effects of chlorin e6 attached to single wall carbon nanotubes through noncovalent interactions. Carbon N Y. 2012;50:1681-1689.

138. Wang L, Shi J, Liu R, et al. Photodynamic effect of functionalized single-walled carbon nanotubes: a potential sensitizer for photodynamic therapy. Nanoscale. 2014;6(9):4642-4651.

139. Erbas S, Gorgulu A, Kocakusakogullari M, Akkaya EU. Non-covalent functionalized SWCNTs as delivery agents for novel Bodipy-based potential PDT sensitizers. Chem Commun. 2009;33:4956-4958.

140. Huang P, Lin J, Yang D, Zhang C, Li Z, Cui D. Photosensitizer-loaded dendrimer-modified multi-walled carbon nanotubes for photodynamic therapy. J Control Release. 2011;152(suppl 1):e33-e34.

141. Shi J, Ma R, Wang L, et al. The application of hyaluronic acid-derivatized carbon nanotubes in hematoporphyrin monomethyl ether-based photodynamic therapy for in vivo and in vitro cancer treatment. Int $J$ Nanomedicine. 2013;8:2361-2373.

142. Zhang P, Huang H, Huang J, et al. Noncovalent ruthenium(II) complexes-single-walled carbon nanotube composites for bimodal photothermal and photodynamic therapy with near-infrared irradiation. ACS Appl Mater Interfaces. 2015;7(41):23278-23290.

143. Marangon I, Ménard-Moyon C, Silva AKA, Bianco A, Luciani N, Gazeau F. Synergic mechanisms of photothermal and photodynamic therapies mediated by photosensitizer/carbon nanotube complexes. Carbon N Y. 2016;97:110-123.
International Journal of Nanomedicine

\section{Publish your work in this journal}

The International Journal of Nanomedicine is an international, peerreviewed journal focusing on the application of nanotechnology in diagnostics, therapeutics, and drug delivery systems throughout the biomedical field. This journal is indexed on PubMed Central, MedLine, CAS, SciSearch ${ }^{\circledR}$, Current Contents ${ }^{\circledR} /$ Clinical Medicine,

\section{Dovepress}

Journal Citation Reports/Science Edition, EMBase, Scopus and the Elsevier Bibliographic databases. The manuscript management system is completely online and includes a very quick and fair peer-review system, which is all easy to use. Visit http://www.dovepress.com/ testimonials.php to read real quotes from published authors. 